OPEN ACCESS

Edited by:

Yuichi Hattori,

University of Toyama, Japan

Reviewed by:

Masao Endoh,

Yamagata University, Japan

Canan G. Nebigil,

Centre National de la Recherche

Scientifique (CNRS), France

*Correspondence:

Hitoshi Kurose

hikurose@phar.kyushu-u.ac.jp

Specialty section:

This article was submitted to

Experimental Pharmacology

and Drug Discovery,

a section of the journal

Frontiers in Pharmacology

Received: 17 August 2018

Accepted: 30 October 2018

Published: 27 November 2018

Citation:

Mangmool S, Parichatikanond W and Kurose H (2018) Therapeutic Targets for Treatment of Heart Failure: Focus on GRKs and $\beta$-Arrestins

Affecting $\beta A R$ Signaling.

Front. Pharmacol. 9:1336.

doi: 10.3389/fphar.2018.01336

\section{Therapeutic Targets for Treatment of Heart Failure: Focus on GRKs and $\beta$-Arrestins Affecting $\beta$ AR Signaling}

\author{
Supachoke Mangmool'1, Warisara Parichatikanond ${ }^{1}$ and Hitoshi Kurose ${ }^{2 *}$ \\ ${ }^{1}$ Department of Pharmacology, Faculty of Pharmacy, Mahidol University, Bangkok, Thailand, ${ }^{2}$ Department of Pharmacology \\ and Toxicology, Graduate School of Pharmaceutical Sciences, Kyushu University, Fukuoka, Japan
}

Heart failure (HF) is a heart disease that is classified into two main types: HF with reduced ejection fraction (HFrEF) and HF with preserved ejection fraction (HFpEF). Both types of HF lead to significant risk of mortality and morbidity. Pharmacological treatment with $\beta$-adrenergic receptor ( $\beta A R$ ) antagonists (also called $\beta$-blockers) has been shown to reduce the overall hospitalization and mortality rates and improve the clinical outcomes in HF patients with HFrEF but not HFpEF. Although, the survival rate of patients suffering from HF continues to drop, the management of HF still faces several limitations and discrepancies highlighting the need to develop new treatment strategies. Overstimulation of the sympathetic nervous system is an adaptive neurohormonal response to acute myocardial injury and heart damage, whereas prolonged exposure to catecholamines causes defects in $\beta A R$ regulation, including a reduction in the amount of $\beta A R s$ and an increase in $\beta A R$ desensitization due to the upregulation of $G$ proteincoupled receptor kinases (GRKs) in the heart, contributing in turn to the progression of HF. Several studies show that myocardial GRK2 activity and expression are raised in the failing heart. Furthermore, $\beta$-arrestins play a pivotal role in $\beta A R$ desensitization and, interestingly, can mediate their own signal transduction without any G proteindependent pathway involved. In this review, we provide new insight into the role of GRKs and $\beta$-arrestins on how they affect $\beta A R$ signaling regarding the molecular and cellular pathophysiology of HF. Additionally, we discuss the therapeutic potential of targeting GRKs and $\beta$-arrestins for the treatment of HF.

Keywords: $\beta$-adrenergic receptor, $\beta$-arrestin, G protein-coupled receptor kinase, heart failure, $\beta$-blocker

\section{HEART FAILURE}

Heart failure (HF) is a heart disease with high morbidity and mortality. Based on measurement of the left ventricular ejection fraction (LVEF), HF with an LVEF less than $40 \%$ corresponds to HF with reduced ejection fraction (HFrEF) whereas HF with normal LVEF $(\geq 50 \%)$ is termed $\mathrm{HF}$ with preserved ejection fraction (HFpEF). The therapeutic goals in patients with $\mathrm{HF}$ are to improve the clinical outcome and quality of life of HF patients, and also to reduce hospitalization and mortality rates. Angiotensin-converting enzyme inhibitors (ACEIs) and $\beta$-adrenergic receptor antagonists ( $\beta$-blockers) have been shown to improve clinical outcomes and survival in patients with HFrEF and, therefore, are recommended for HFrEF treatment according to the ESC 2016 guideline for treatment of acute and chronic HF (Ponikowski et al., 2016). In several clinical trials, 
ACEIs, angiotensin receptor blockers (ARBs), mineralocorticoid receptor antagonists (MRAs), and $\beta$-blockers have been shown to reduce mortality and morbidity in patients with HFrEF (Ponikowski et al., 2016). However, none of these drugs have convincingly improved clinical outcomes and reduced morbidity/mortality in patients with HFpEF (Andersen and Borlaug, 2014; Ponikowski et al., 2016; Yamamoto, 2017; Bonsu et al., 2018).

Although $\beta$-blockers have dramatically reduced morbidity and mortality rates, $\beta$-blockers have limited effectiveness in some HF patients and have adverse effects. Thus, several barriers remain in the management of $\mathrm{HF}$ and new treatment strategies for $\mathrm{HF}$ need to be developed. In this review, we provide insight into the potential therapeutic targets for the treatment of HF, focusing in particular on $G$ protein-coupled receptor kinases (GRKs) and $\beta$-arrestins.

\section{G PROTEIN-COUPLED RECEPTOR KINASE}

Upon agonist binding to $\beta$-adrenergic receptor $(\beta \mathrm{AR})$, the heterotrimeric $G$ proteins dissociate into $G \alpha$ and $G \beta \gamma$ subunits which activate diverse downstream effectors and play fundamental roles in numerous cellular functions. Stimulation with an agonist simultaneously triggers the termination of the $\beta A R$ signaling and the rapid reduction of the receptor responsiveness through a process called "receptor desensitization." The phosphorylation by GRKs of agonistoccupied $\beta$ AR corresponds to the first step of desensitization occurring within seconds to minutes which induces the recruitment of cytosolic $\beta$-arrestins to the receptor complex located on the plasma membrane. After binding, $\beta$-arrestins sterically inhibit further the interaction of $\beta A R$ with G $\alpha$ s resulting in their uncoupling of $\beta A R$. GRKs and $\beta$-arrestins also play an important role in $\beta A R$ internalization, trafficking, and resensitization (Moore et al., 2007). In addition, GRKs can directly interact as scaffolding proteins with many signaling proteins, resulting in modulation of various physiological responses, and GRKs also phosphorylate several proteins other than receptors (Kurose, 2011; Watari et al., 2014).

GRKs preferentially phosphorylate GPCRs in an activated (agonist-bound) state at serine and threonine residues localized within either the third intracellular loop (ICL3) or C-terminal tail (Ferguson, 2001). This GRK-mediated phosphorylation of GPCR at these residues may regulate the stability of $\beta$-arrestin/GPCR complexes (Oakley et al., 1999). Even though GRK phosphorylation sites have been identified for some receptors, no distinct GRK phosphorylation consensus sequence/motif has been identified. The $\beta_{2} \mathrm{AR}$ has a short ICL3 and a long C-terminal tail containing several serine and threonine residues. Mutation of all phosphorylation sites within the ICL and the C-terminal tail of $\beta_{2} \mathrm{AR}$ attenuates GRK-mediated phosphorylation of receptors (Bouvier et al., 1988). In addition, the ICL3 of $\beta_{2} A R$ is associated with $G$ protein activation and the specificity of the interaction between receptor and $G$ protein (Reiter and Lefkowitz, 2006). On the contrary, human $\beta_{1} \mathrm{AR}$ is resistant to GRK-mediated desensitization and internalization. Human $\beta_{1}$ AR does not internalize upon agonist stimulation and has lower affinity for $\beta$-arrestins than $\beta_{2} \mathrm{AR}$ (Suzuki et al., 1992; Shiina et al., 2000). However, mouse $\beta_{1}$ AR is internalized by agonist stimulation (Volovyk et al., 2006). The physiological meaning of this species difference is unknown. Among GRKs, GRK2 has a fairly strict dependency of agonist binding for receptor phosphorylation, while GRK5 has the higher ability for phosphorylating agonist-unbound receptor as compared to GRK2 (Tran et al., 2007). GRK5-promoted phosphorylation of agonist-unbound receptor may help the receptor to activate $\beta$-arrestin-biased signaling that is primarily activated by antagonists. GRK-catalyzed phosphorylation of $\beta_{1} \mathrm{AR}$ enhances $\beta$-arrestin-mediated signaling. It has been reported that $\beta_{1} \mathrm{AR}$-mediated biased signaling in the heart requires GRK5-promoted phosphorylation (Nakaya et al., 2012).

Interaction between GRKs and the activated $\beta$ ARs on the plasma membrane is necessary for GRK-catalyzed receptor phosphorylation. A recent study revealed a dynamic mechanism of complex formation between GRK5 and $\beta_{2}$ AR (Komolov et al., 2017). Two major domains of GRK5 [the regulator of G protein signaling homology $(\mathrm{RH})$ and the catalytic domain] are able to dissociate following binding to activated $\beta_{2}$ AR causing disruption of a transient electrostatic contact between these two domains. These changes facilitate contacts between ICL2, ICL3, and the C-terminal tail of $\beta_{2} \mathrm{AR}$ with the GRK5 RH bundle domain, the membrane-binding surface, and the kinase catalytic pocket, respectively (Komolov et al., 2017).

\section{GRK FAMILY}

According to their amino acids sequence and ternary structural homology, GRK family members can be divided into three groups as follows: rhodopsin kinase subfamily (GRK1 and GRK7), $\beta$ AR kinase ( $\beta$ ARK) subfamily (GRK2 and GRK3), and GRK4 subfamily (GRK4, GRK5, and GRK6) (Penn et al., 2000; Penela et al., 2003). The structure of GRKs consists of three distinct domains: an amino terminal (N-terminal) domain, a central highly conserved catalytic domain, and a carboxyl terminal (Cterminal) domain. The N-terminal domain involved in receptor binding and recognition of the activated receptor contains a region of homology to the regulator of $G$ protein signaling protein and $\mathrm{Ca}^{2+} /$ calmodulin-binding domain (Penn et al., 2000; Penela et al., 2003). The N-terminal domain of GRK4, GRK5, and GRK6 contains a phosphatidylinositol 4,5-bisphosphate $\left(\mathrm{PIP}_{2}\right)$-binding site allowing the amplification of their kinase activities (Pitcher et al., 1998), whereas the N-terminus of GRK2 contains a G $\beta \gamma$-binding site causing GRK2 binding to the plasma membrane (Eichmann et al., 2003). The central domain is highly conserved among GRKs and exerts the kinase catalytic function.

The C-terminal domain of GRKs is involved in plasma membrane targeting and membrane binding by means of post-translational modifications or interaction with membrane phospholipids. The C-terminal domains of GRKs are divergent among subfamilies. GRK1 and GRK7 interact with the plasma 
membrane via a post-translational modification at their C-termini. The C-terminal domain of GRK2 and GRK3 is composed of a pleckstrin homology domain that includes a phospholipid-binding site and a G $\beta \gamma$-binding site (Penn et al., 2000; Penela et al., 2003).

We reported in our previous study that GRK2 has a clathrinbinding motif at its C-terminus domain enabling the kinase to cooperate with the heavy chain of clathrin (Shiina et al., 2001), a step necessary for $\beta A R$ internalization (Mangmool et al., 2006). GRK4 and GRK6 are post-translationally palmitoylated at cysteine residues located in their C-terminal domains, leading to plasma membrane localization and interaction. GRK5 binds to membrane phospholipids through electrostatic interaction of the positively charged amino acid located in its C-terminus. Finally, membrane localization of GRK4, GRK5, and GRK6 is regulated by the interaction with membrane $\mathrm{PIP}_{2}$ via their $\mathrm{PIP}_{2}$-binding sites (Penela et al., 2003). GRKs mediate the desensitization and internalization of $\beta A R s$, including $\beta_{1} A R$ and $\beta_{2} A R$. It is likely that subtype specificity of GRKs underlies observed differences in the regulation of $\beta A R s$. In HEK-293 cells overexpressing GRK2, but not GRK5 and GRK6, the agonist-induced $\beta_{2}$ AR phosphorylation was inhibited by the treatment of clathrin heavy chain siRNA. These results suggest an important role for clathrin in GRK2-mediated $\beta_{2} \mathrm{AR}$ phosphorylation and internalization (Mangmool et al., 2006). In addition, GRK2 phosphorylates four amino acid residues (Thr384, Ser396, Ser401, and Ser407) of the C-terminal tail of $\beta_{2} \mathrm{AR}$ whereas GRK5 phosphorylates six amino acid residues (Thr384, Thr393, Ser396, Ser401, Ser407, and Ser411) of the C-terminal tail of $\beta_{2} \mathrm{AR}$ (Fredericks et al., 1996).

More than hundreds of GPCRs have been identified in the human while seven members only of GRK family have been identified. It is not well understood why a limited number of GRKs regulate various GPCRs. The distribution pattern and expression levels of each GRK seem important factors contributing to their specificity and functional roles in many tissues, including the heart.

\section{GRK EXPRESSION IN THE HEART}

GRK2 (known as $\beta$ ARK1), GRK3, and GRK5 are highly expressed in the human heart, whereas GRK4, GRK6, and GRK7 are only expressed at minimal levels (Ungerer et al., 1993). The distribution of each GRK isoform is different among heart cells. GRK2 and GRK5 are expressed in almost all cardiac cells, whereas GRK3 is detected only in cardiac myocytes (Vinge et al., 2001; Penela et al., 2006). The functional role of GRK subtypes in the heart under normal and pathological conditions may be influenced by their distribution. The functional role of GRK2 in cardiac fibroblasts was recently identified and GRK2 modulates contractility and remodeling following ischemia/reperfusion injury (Woodall et al., 2016). GRK expression and activity are changed in many cardiovascular diseases, especially HF. Thus, the functional roles of GRKs have been extensively studied in the heart as diagnostic markers and/or therapeutic targets for $\mathrm{HF}$ (Hullmann et al., 2016).

\section{ROLE OF GRK IN HF}

Dysregulation of $\beta$ ARs is a pathological hallmark of HF; in particular, $\beta$ ARs are significantly downregulated and desensitized because of the upregulation of GRKs, especially GRK2 and GRK5 (Sato et al., 2015). $\beta$ ARs are targets for GRK-mediated phosphorylation and desensitization, and increased expression and activity of GRK2 in the heart are associated with the loss of $\beta A R$ functions that induces deleterious effects. Although these events lead to the development and progression of $\mathrm{HF}$, the inhibition of GRK2 expression or activity is able to restore cardiac functions (Petrofski and Koch, 2003).

In $\mathrm{HF}$, the increase in catecholamine levels is derived from chronic sympathetic activation, resulting in overstimulation of $\beta$ ARs. The heart adapts to excessive stimulation by blunting the $\beta A R$ responsiveness to catecholamines (Lymperopoulos et al., 2013; de Lucia et al., 2018). This process called $\beta A R$ desensitization requires GRKs. However, desensitization and downregulation of $\beta$ ARs are not sufficient to compensate fully for chronic overstimulation of the sympathetic system. Prolongation of excessive stimulation over time becomes harmful to the heart and is responsible for the majority of $\mathrm{HF}$ (Lymperopoulos et al., 2013; de Lucia et al., 2018). Indeed, $\beta$ AR desensitization is involved in the decrease of $\beta_{1}$ AR expression ( $\beta$ AR downregulation) and the uncoupling of $\beta$ AR from $G$ protein occurs during HF.

Because GRKs are involved in desensitization and downregulation of $\beta \mathrm{AR}$, whether expression and activity of one or more GRKs is increased in HF patients or HF model animals has been extensively investigated in the past several years (Table 1). Chronic administration of isoproterenol resulted in $\beta A R$ desensitization, upregulation of GRK2, and hypertrophy in mouse hearts (Iaccarino et al., 1998b). In addition, several studies have demonstrated that expression and activity of cardiac GRK2 are significantly increased in the failing heart (Ungerer et al., 1993; Harris et al., 2001; Rengo et al., 2011; Sato et al., 2015), indicating that upregulation of GRK2 plays a pivotal role in the $\mathrm{HF}$ associated with the dysfunction of $\beta$ AR-mediated signaling.

Transgenic mice with cardiac-specific overexpression of GRK2 had contractile responses to $\beta A R$ abolished and displayed physiological alterations (e.g., impairment of $\beta A R$ functions and signaling, and cardiac hypertrophy), resulting in a failing heart in these mice (Koch et al., 1995; Rockman et al., 1998). Moreover, GRK2 high expression is detected in patients with end-stage dilated HF (Ungerer et al., 1994) and in several conditions related to HF development, including myocardial ischemia (Ungerer et al., 1996) and hypertension (Gros et al., 1997). Taken together, these results show that GRK2 dysfunction plays a pivotal role in heart diseases. However, the exact mechanism responsible for upregulation of GRK2 following $\beta$ AR overstimulation in the compromised heart is not clearly understood.

Conversely, attenuation of GRK2 activity by expression of the carboxyl terminal domain of GRK2 ( $\beta$ ARKct), which inhibits agonist-dependent GRK2 translocation to the membrane, or a reduction in GRK2 expression, enhanced cardiac functions (Koch et al., 1995). In addition, overexpression of $\beta$ ARKct could restore the diminished $\beta \mathrm{AR}$ contractile function and largely reverse the 
TABLE 1 | Changes in GRKs and $\beta$-arrestins levels and activities in animal models of HF and HF patients.

\begin{tabular}{|c|c|c|}
\hline Experiments/Populations & Results & Reference \\
\hline Human dilated cardiomyopathy & $\begin{array}{l}\text { - Increased GRK2 and GRK5 mRNA levels } \\
\text { - Unchanged GRK3 mRNA level }\end{array}$ & Dzimiri et al., 2004 \\
\hline Human failing heart & - Elevated GRK2 mRNA level and activity in failing heart & Ungerer et al., 1993 \\
\hline Human failing heart & - Increased GRK2 and GRK5 (but not GRK3) protein levels in left ventricles & Agüero et al., 2012 \\
\hline Human failing heart & $\begin{array}{l}\text { - Increased GRK2 mRNA level } \\
\text { - Slightly increased GRK3 mRNA level } \\
\text { - Unchanged } \beta \text {-arrestin1 and } \beta \text {-arrestin2 mRNA levels }\end{array}$ & Ungerer et al., 1994 \\
\hline Rabbit failing heart & - Elevated GRK2 protein level and activity in post-myocardial infarction (post-MI) heart & Maurice et al., 1999 \\
\hline Isolated perfused rat heart & - Increased GRK2 mRNA level and activity during myocardial ischemia & Ungerer et al., 1996 \\
\hline Rat model of congestive heart failure (CHF) & $\begin{array}{l}\text { - Increased GRK2, GRK5, } \beta \text {-arrestin1, and } \beta \text {-arrestin2 mRNA levels in failing heart } \\
\text { - Increased GRK2, GRK5, and } \beta \text {-arrestin1 in post-infarction failing heart }\end{array}$ & Vinge et al., 2001 \\
\hline Pacing-induced $\mathrm{CHF}$ in pig & $\begin{array}{l}\text { - Increased total GRK activity } \\
\text { - Increased GRK5 mRNA and protein levels } \\
\text { - Unchanged GRK2 mRNA and protein levels }\end{array}$ & Ping et al., 1997 \\
\hline Pressure-overload cardiac hypertrophy in mice & - Increased GRK activity & Choi et al., 1997 \\
\hline
\end{tabular}

impaired cardiac functions in animal models of $\mathrm{HF}$, such as muscle LIM protein (MLP) knockout (KO) mice (Rockman et al., 1998) and calsequestrin-overexpression mice (Harding et al., 2001). Thus, GRK2 expression in the heart appears to be related with cardiac contractile function. Previous studies have provided strong evidence that GRK2 plays a pivotal role in the $\beta A R-$ mediated development of HF (Iaccarino et al., 1998b; White et al., 2000; Raake et al., 2008) and the increase of GRK2 expression can be used as an early marker for HF (Rengo et al., 2011; Lymperopoulos et al., 2013). Taken together, GRK2 acts as a central modulator of $\beta A R$ signaling in the heart and could serve as a HF diagnosis biomarker.

Moreover, GRK2 also plays an important role in the $\beta$ AR-mediated cardiac insulin resistance. Overstimulation of myocardial $\beta_{2}$ ARs and upregulation of GRK2 are associated with insulin resistance in the heart (Mangmool et al., 2017). Chronic stimulation of $\beta_{2} \mathrm{ARs}$, but not $\beta_{1} \mathrm{ARs}$, resulted in impaired insulin-induced glucose uptake and IRS-1 phosphorylation (Cipolletta et al., 2009) and also significantly reduced the actions of insulin to induce GLUT4 expression and translocation in cardiac myocytes and heart tissues (Mangmool et al., 2016). In addition, upregulation of $\beta_{2} \mathrm{AR}$ enhances GRK2 expression that is related with $\beta A R$-induced insulin resistance in heart tissue (Ciccarelli et al., 2011) and in animal models of insulin resistance (Cipolletta et al., 2009). Thus, inhibition of GRK2 activity leads to enhanced insulin sensitivity in the heart. In animal models of diabetes, inhibition of GRK2 and GRK3 through synthetic peptides rescues glucose tolerance and improves insulin sensitivity (Anis et al., 2004). Other myocardial GRK isoform functions in this context, including GRK5, and the precise mechanism of GRK2 for $\beta$ AR-mediated cardiac insulin resistance represent interesting areas of future research.
During pathological states of heart conditions, the expression of other GRK isoforms is also altered. GRK3 and GRK5 have been demonstrated to participate in the pathogenesis of HF. GRK5 expression is increased in animal models of HF (Ping et al., 1997; Vinge et al., 2001; Yi et al., 2002). GRK5 expression is also increased in dilated cardiomyopathy and volume-overloaded human left ventricle (Dzimiri et al., 2004), whereas the expression of GRK3 remains stable in dilated cardiomyopathy and is slightly induced in patients with right ventricular volume overload (Ungerer et al., 1993, 1996; Dzimiri et al., 2004). Nevertheless, dynamic alterations of GRK3 and GRK5 related to the development of HF remain to be elucidated.

In a model of transgenic mice overexpressing cardiac-specific GRK5, a considerable decline of $\beta A R$ signaling and inotropic responsiveness was detected (Rockman et al., 1996). Interestingly, overexpression of GRK3 in mice does not affect $\beta$ AR signaling and cardiac function (Iaccarino et al., 1998a), indicating that GRK3 does not share functional characteristics of GRK2, even though these two GRKs belong to the same subfamily. GRK3 might play a role desensitization of in $\alpha_{1} \mathrm{AR}$ rather than $\beta \mathrm{AR}$. Phosphorylation of $\alpha_{1}$ AR by GRK3 contributed to cardiac hypertrophy and dysfunctions that occur during chronic pressure overload (von Leuder et al., 2012). In addition, inhibition of GRK3 activity using GRK3ct preserves cardiac function and prevents the development of HF after chronic pressure overload (von Leuder et al., 2012).

Although overexpression of GRK5 in the heart results in attenuation of $\beta$ AR-mediated signaling and function (Rockman et al., 1996), the complete deletion of GRK5 as in GRK5$\mathrm{KO}$ mice does not significantly affect $\beta$ AR-mediated responses in the heart (Gainetdinov et al., 1999). However, cardiac hypertrophy and failing heart after pressure overload are detected 
in transgenic mice with cardiac-specific overexpression of GRK5 (Martini et al., 2008). These detrimental effects of GRK5 are derived from its activity in the nucleus. GRK5 activity in the nucleus may be associated with a progression of a maladaptive cardiac hypertrophy that is independent of $\beta$ ARs (Martini et al., 2008). In addition, cardiac-specific deletion of GRK5 exhibits cardioprotective effects against pathological hypertrophy and HF after pressure overload (Gold et al., 2012). GRK5 is also found to be required for $\beta_{1} \mathrm{AR}$-mediated transactivation of epidermal growth factor receptor (EGFR) that confers cardioprotection in mice (Noma et al., 2007). Since GRK5 has been shown to have both detrimental and cardioprotective effects, regulation and compartmentalization of GRK5 in normal and failing hearts represent the most important issues when considering the inhibition of GRK5 as therapeutic target for HF.

The GRK5-Leu41 polymorphism of GRK5, with leucine at position 41 substituted for glutamine, is abundantly found in African American populations. Interestingly, GRK5-Leu41 is a gain-of-function genetic polymorphism that enhances desensitization of $\beta$ AR (Liggett et al., 2008). GRK5-Leu41 allele decreases the activity of $\beta$ AR signaling in a similar way to a partial blockade of $\beta \mathrm{AR}$ by $\beta$-blockers, promoting cardioprotective effects against experimental catecholamine-induced cardiomyopathy. HF patients with the GRK5-Leu41 allele show improved survival (Liggett et al., 2008), suggesting that modulation of GRK5 remains a powerful target for the treatment of HF. However, the specific contribution of each GRK isoform to the development of a failing heart remains to be determined.

\section{THERAPEUTIC APPROACHES OF GRKs FOR THE TREATMENT OF HF}

Even though $\beta$-blockers inhibit HF progression and improve the quality of life in HF patients, these drugs show modest effectiveness in improving the contractile functions of the failing heart in animal models. If increased GRK activity and expression are important elements in desensitization and dysregulation of $\beta A R$ in HF patients, potential therapeutic strategies aimed to modulate GRKs by preventing their expression and activity would consequently boost the ability of cardiac myocytes to respond to adrenergic stimulation (Koch et al., 1995; Korzick et al., 1997). For example, in animal models of HF, expression of $\beta A R K c t, a$ GRK2 inhibitor, delays the progression of functional and biochemical modifications of the $\beta A R$ signaling associated with HF (Rockman et al., 1998). Thus, inhibition of GRK by different strategies might be a novel therapeutic approach for restoring cardiac functions in the failing heart (Table 2). We will summarize results and strategies to inhibit GRK activity that could help to design novel therapeutic strategies for HF management.

\section{BARKct (or GRK2ct)}

$\beta$ ARKct, a polypeptide of 194 amino acids, consists of the G $\beta \gamma$ binding domain of GRK2 (Hullmann et al., 2016).
Inhibition of GRK2 using $\beta$ ARKct dramatically improves cardiac contractility in animal models of HF (Hata et al., 2004). The mechanism of action proposed for $\beta A R K c t$ is to inhibit the activity of endogenous GRK2 by competing with the endogenous GRK2 for G $\beta \gamma$-binding, thus, attenuating GRK2 membrane translocation and activation, resulting in a reduction of GRK2-mediated BAR desensitization (Koch et al., 1995). Providing inhibitory $\beta$ ARKct to several animal models of $\mathrm{HF}$ leads to the delay of cardiac dysfunction and increased survival (Table 2). Overexpression of $\beta$ ARKct improves cardiac functions, prevents cardiac remodeling and cardiac hypertrophy, and increases survival rates in several animal models of HF (White et al., 2000; Shah et al., 2001). Moreover, cardiacspecific $\beta$ ARKct overexpression prevents cardiac remodeling and development of HF in MLP KO mice, a model of dilated cardiomyopathy with elevated GRK2 levels in the heart, suggesting that inhibition of GRK2 activity represents an approach to prevent the development of HF (Rockman et al., 1998). Similarly, cardiac-specific overexpression of $\beta$ ARKct results in cardiac contractility improvement, a delay of adverse remodeling, and a prolonged lifespan in HF model mice with calsequestrin overexpression, which show severe cardiomyopathy and markedly reduced survival rate (Harding et al., 2001). The beneficial effects of $\beta$ ARKct were enhanced by co-treatment with metoprolol, suggesting that inhibition of GRK2 provides a better clinical outcome than in HF patients treated only by $\beta$-blockers (Harding et al., 2001). When cardiac myocytes isolated from heart tissues from $\mathrm{HF}$ patients were infected by adenovirus expressing $\beta$ ARKct, the $\beta$ ARKct-overexpressing myocytes exhibited significant increases of the heart ability to contract and relax in response to adrenergic stimulation (Williams et al., 2004). Thus, inhibition of GRK2 in the failing heart has beneficial effects on cardiac performance. However, it should be noted that $\beta$ ARKct might mediate its beneficial effects via mechanisms distinct from inhibiting GRK2, as $\beta$ ARKct is able to inhibit several $G \beta \gamma$-mediated signaling pathways.

Even though gene therapy using $\beta A R K c t$ represents a promising strategy for the treatment of $\mathrm{HF}$, the large size of $\beta A R K c t$, and the virus requirement for heart-specific expression may represent major obstacles for clinical development. Small peptide or synthetic compounds that specifically inhibit GRK activity (selective GRK inhibitor) may provide a much easier way at a lower cost when searching for therapeutic approaches for HF. These data support the use of GRK2 inhibitor, including $\beta$ ARKct as a promising therapeutic approach for the treatment of chronic HF (Rengo et al., 2011). The effects of GRK2 inhibition might be similar or greater than those of classical $\beta$-blocker therapy (Reinkober et al., 2012).

\section{PAROXETINE}

Paroxetine is a selective serotonin reuptake inhibitor (SSRI) antidepressant that is found to be a GRK2 inhibitor (Homan et al., 2014). Paroxetine binds to GRK2 and inhibits GRK2 catalytic activity more potently than other GRK isoforms 
TABLE 2 | GRKs as the therapeutic targets for HF treatment.

\begin{tabular}{|c|c|c|}
\hline Experiments/Populations & Results & Reference \\
\hline $\begin{array}{l}\text { Transgenic mice with cardiac-specific overexpression of } \\
\beta A R K c t\end{array}$ & $\begin{array}{l}\text { - Overexpression of } \beta A R K c t \text { enhanced cardiac contractility and } \\
\text { improved cardiac functions }\end{array}$ & Koch et al., 1995 \\
\hline $\begin{array}{l}\text { Cardiac-specific overexpression of } \beta A R K c t \text { in HF model } \\
\text { mice (MLP KO mice) }\end{array}$ & $\begin{array}{l}\text { - Overexpression of } \beta \text { ARKct prevented the progression of } \\
\text { cardiomyopathy }\end{array}$ & Rockman et al., 1998 \\
\hline $\begin{array}{l}\text { Cardiac-specific overexpression of } \beta A R K c t \text { in HF model } \\
\text { mice (calsequestrin overexpressed mice) }\end{array}$ & $\begin{array}{l}\text { - Overexpression of } \beta \text { ARKct markedly prolonged survival and restored } \\
\text { cardiac functions in failing heart }\end{array}$ & Harding et al., 2001 \\
\hline $\begin{array}{l}\beta A R K c t \text { was expressed by adenovirus-mediated gene } \\
\text { transfer in ventricular myocytes isolated from human } \\
\text { failing heart }\end{array}$ & $\begin{array}{l}\text { - Expression of } \beta \text { ARKct improved contractile function and } \\
\beta A R \text {-mediated responses in failing human cardiac myocytes }\end{array}$ & Williams et al., 2004 \\
\hline GRK2 gene ablation in mice of post-MI model & $\begin{array}{l}\text { - Deletion of GRK2 before coronary artery ligation delayed maladaptive } \\
\text { post-infarction remodeling and restored } \beta A R \text { signaling and functions } \\
\text { - GRK2 deletion initiated } 10 \text { days after MI enhanced survival, improved } \\
\text { contractility, and inhibited cardiac remodeling }\end{array}$ & Raake et al., 2008 \\
\hline Mice of post-MI HF model & $\begin{array}{l}\text { - Paroxetine prevented HF development due to inhibition of GRK2 } \\
\text { activity }\end{array}$ & Schumacher et al., 2015 \\
\hline Cardiac myocytes (in vitro) and mice (in vivo) & $\begin{array}{l}\text { - Paroxetine increased } \beta A R-\text { mediated cardiomyocyte contractility } \\
\text { in vitro } \\
\text { - Paroxetine improved } \beta \text { AR-mediated left ventricular inotropic reserve } \\
\text { in vivo }\end{array}$ & Thal et al., 2012 \\
\hline
\end{tabular}

(Thal et al., 2011). From crystallization and structure analysis, paroxetine was reported to occupy the active site of GRK2 leading to the stabilization of the GRK2 kinase domain in a unique inactive conformation (Thal et al., 2011). Paroxetine enhances $\beta$ AR-mediated shortening and contraction of isolated cardiac myocytes and increases $\beta$ AR-mediated left ventricular inotropic reserve in vivo (Thal et al., 2012), similar to $\beta$ ARKct.

In addition, administration of paroxetine to an HF mouse model demonstrated an improvement of LV structure and function and attenuated the expression of the fetal genes, representing an index of progression to HF (Schumacher et al., 2015). These cardioprotective effects of paroxetine are due to the inhibitory activity of GRK2 but not the SSRI activity of paroxetine, suggesting that paroxetine prevents HF progression in an SSRI-independent manner. Moreover, equivalent doses of fluoxetine, another SSRI, did not show any of these effects. The result emphasizes that the effects of paroxetine are due to GRK2 inhibition (Schumacher et al., 2015). Thus, paroxetinemediated inhibition of GRK2 enhances cardiac performance, reverses sympathetic overstimulation, normalizes the myocardial $\beta A R$ functions, and protects the heart after myocardial infarction (MI) (Table 2). These data demonstrate that paroxetine-mediated inhibition of GRK2 improves cardiac function after MI and represents a potential repurposing of this drug, as well as starting point for innovative small-molecule GRK2 inhibitor development.

Interestingly, chronic treatment with various SSRIs (e.g., fluoxetine, paroxetine) stimulated serotonin receptor type $4\left(5-\mathrm{HT}_{4} \mathrm{R}\right)$ desensitization in cerebral regions implicated in depression, including basal ganglia and hippocampus (Licht et al., 2009; Vidal et al., 2009). Moreover, upregulation of GRK2 significantly suppressed serotonin-induced cAMP generation in COS-7 cells, suggesting a negative regulatory role for GRK2 at the 5- $\mathrm{HT}_{4} \mathrm{R}$ level (Barthet et al., 2005). In addition, serotonin-induced $5-\mathrm{HT}_{4 \mathrm{~A}} \mathrm{R}$ internalization was inhibited by expression of either dominant negative (DN) GRK2 and DN $\beta$-arrestin1 ( $\left(\operatorname{arr}_{1319-418}\right)$ in HEK-293 cells, suggesting that GRK2 and $\beta$-arrestin are involved in the trafficking of $5-\mathrm{HT}_{4} \mathrm{Rs}$ (Mnie-Filali et al., 2010).

GRK-mediated phosphorylation of $5-\mathrm{HT}_{4} \mathrm{R}$ exhibits high affinity for $\beta$-arrestins, which binds to the phosphorylated receptor and inhibit coupling with $G$ proteins. This results in the inhibition of further signaling (Mnie-Filali et al., 2010). The $5-\mathrm{HT}_{4} \mathrm{R} / \mathrm{GRK} / \beta$-arrestin complex may confer different signaling and regulatory characteristics to the $5-\mathrm{HT}_{4}$ receptors, leading perhaps to new functional roles and eventually therapeutic implications. Since paroxetine is an inhibitor of GRK2 that plays an important role in $5-\mathrm{HT}_{4} \mathrm{R}$ desensitization and trafficking, the exact mechanisms by which paroxetine affects the desensitization and the trafficking of various serotonin receptors, especially 5$\mathrm{HT}_{4} \mathrm{R}$ remain to be elucidated.

\section{OTHER SYNTHETIC GRK INHIBITORS}

Since GRK2 and GRK5 are upregulated in the failing heart and play major roles in the progression of cardiac dysfunction, including HF, a selective inhibitor of GRK2 and/or GRK5 might represent a promising target for $\mathrm{HF}$ treatment. Balanol 
is a synthetic compound that was found to inhibit GRK2 activity (Setyawan et al., 1999; Tesmer et al., 2010). However, balanol also inhibits other protein kinases such as protein kinase $\mathrm{A}$ (PKA), protein kinase $\mathrm{C}(\mathrm{PKC})$, and protein kinase G (PKG). A selective GRK2 inhibitor was developed by a twostep rational drug design process, and compound 10 (Methyl 5[2-(5-nitro-2-furyl)vinyl]-2-furoate) was found to inhibit GRK2 more selectively than PKA (Iino et al., 2002). This compound was the first inhibitor that was able to distinguish GRK2 from PKA, a protein kinase that has a similar adenine-binding pocket.

A GRK2 inhibitor screening has been performed using a compound library, leading to identify various novel candidates (Homan et al., 2015). Currently, most active compounds can be divided into two chemical classes: indazole/dihydropyrimidine-containing compounds that strongly inhibit GRK2 and pyrrolopyrimidine-containing compounds that are selective for inhibition of GRK1 and GRK5 (Homan et al., 2014, 2015). Several new GRK inhibitors are also synthesized such as GSK180736A and GSK2163632A. These compounds were co-crystallized with GRKs (Homan et al., 2015). GSK180736A is a selective GRK2 inhibitor, which binds to GRK2 in a similar way to paroxetine, whereas GSK2163632A occupies a novel region of the GRK active site that is related to its selectivity (Homan et al., 2015). Further development by in silico screening, using GSK180736A and CCG215022 as templates, identified two new compounds (compounds 33 and 37) as potent GRK2 and GRK5 inhibitors (Waldschmidt et al., 2018). The $\mathrm{IC}_{50}$ value of GSK180736A toward GRK2 and GRK5 are $0.77 \mu \mathrm{M}$ and $>100 \mu \mathrm{M}$, respectively (Waldschmidt et al., 2018). However, the screening did not identify any compounds that exhibited high GRK5 selectivity.

Overstimulation of $\beta \mathrm{AR}$ is associated with the pathogenesis of insulin resistance in the heart (Mangmool et al., 2017). For instance, chronic $\beta$ AR stimulation causes the development of insulin resistance through an increase in GRK2 levels (Cipolletta et al., 2009). Moreover, upregulation of GRK2 impairs cardiac glucose uptake and promotes insulin resistance after MI (Ciccarelli et al., 2011). The small peptides (e.g., KRX683107 and KRK-683124) derived from the catalytic domain of GRK2 and GRK3 have been shown to improve glucose metabolism. By modulating GRK2 and GRK3 activities, these two peptides enhanced GPCR-mediated signal transduction, resulting in an antidiabetic effect (Anis et al., 2004). In animal models of diabetes, inhibition of GRK2 and GRK3 through these synthetic peptides rescues glucose tolerance and enhances insulin sensitivity (Anis et al., 2004). Thus, these small peptides could be useful as GRK inhibitors by interfering with kinasesubstrate interactions. However, the efficacies of these small peptides in animal model of HF are not known. To develop specific inhibitors for GRKs, the sequence of the first intracellular loop (ICL1) of the $\beta_{2} \mathrm{AR}$ was synthesized and found to inhibit GRKs (Winstel et al., 2005). IC IC $_{50}$ value of a peptide with the sequence AKFERLQTVTNYFITSE for GRK2 is $0.6 \mu \mathrm{M}$. This peptide also inhibited GRK3 and GRK5 with an $\mathrm{IC}_{50}$ of 2.6 and $1.6 \mu \mathrm{M}$, respectively (Winstel et al., 2005). Furthermore, the peptide inhibitor did not suppress PKC and PKA activities because ICL1 of $\beta_{2} A R$ presents selectivity GRK2 over PKC and PKA (Benovic et al., 1990). However, the efficacy of these synthetic and peptide inhibitors of GRKs remain to be tested in animal models of HF, which means that another 6 to 10 years are needed before they can be tested in human if they show promising effects in animal models and preliminary safety data are obtained.

\section{$\beta$-ARRESTINS}

Stimulation of $\beta$ ARs with agonists leads to GRK-mediated receptor phosphorylation that promotes the recruitment of $\beta$-arrestins to phosphorylated $\beta$ ARs. Then $\beta$-arrestins sterically inhibit further $\mathrm{G}$ protein coupling to $\beta$ ARs. After $\beta$-arrestin binds to and forms a complex with $\beta$ AR and GRK, $\beta$-arrestin promotes internalization of $\beta$ AR into the cytosol, which can lead to receptor degradation (downregulation) and receptor recycling back to the plasma membrane (Moore et al., 2007). Thus, $\beta$-arrestins play essential roles in $\beta \mathrm{AR}$ internalization and trafficking (Lefkowitz and Shenoy, 2005; Lefkowitz et al., 2006).

Although both $\beta_{1}$ ARs and $\beta_{2}$ ARs are Gs protein-coupled receptors, their functional properties differ and lead to subtypespecificity interaction with $\beta$-arrestins. For instance, the binding of $\beta$-arrestin- 1 and -2 to the third intracellular loop (ICL3) and the C-terminal tail of $\beta_{1} A R$ is lower than that for $\beta_{2} \mathrm{AR}$ (Shiina et al., 2000). A chimeric $\beta_{2} \mathrm{AR}$ containing the C-terminal tail of $\beta_{1} \mathrm{AR}$ lost its ability to promote $\beta$-arrestin2mediated ERK nuclear translocation (Kobayashi et al., 2005). Moreover, stimulation of $\beta_{1} \mathrm{AR}$, but not $\beta_{2} \mathrm{AR}$, induces a conformational change in $\beta$-arrestin that promotes a stable $\beta$-arrestin/Epac/Ca ${ }^{2+} /$ calmodulin-dependent protein kinase II (CaMKII) complex (Mangmool et al., 2010). The association of $\beta$-arrestin with $\beta_{1} \mathrm{AR}$ stabilizes this complex and promotes CaMKII signaling (Mangmool et al., 2010). It is interesting that $\beta$-arrestin deletion results in differential ERK activation in a $\beta$ AR subtype-selective manner (O'Hayre et al., 2017; Grundmann et al., 2018). Deletion of $\beta$-arrestin results in enhancement of $\beta_{2}$ AR-mediated ERK activation, but decrease of $\beta_{1}$ AR-mediated ERK activation. Enhancement of $\beta_{2} A R$-mediated ERK activation is due to the impaired desensitization of $\beta_{2} \mathrm{AR}$ and decrease of $\beta_{1}$ AR-mediated ERK activation is due to the lack of the scaffolding function of $\beta$-arrestin.

In addition to regulate GPCR endocytosis and trafficking, $\beta$-arrestins themselves function as scaffolding proteins and signal transducers to stimulate various downstream effectors, including MAPK cascades induction (e.g., ERK1/2 and JNK3), Src activation (Lefkowitz and Shenoy, 2005; Lefkowitz et al., 2006), and EGFR transactivation (Noma et al., 2007). Furthermore, $\beta$-arrestins can interact and form a complex with CaMKII (Mangmool et al., 2010). Complex formation facilitates CaMKII activation, which plays a key role in cardiac hypertrophy and apoptosis that cause HF (Mollova et al., 2015). The ability of $\beta$-arrestins to desensitize $\beta$ ARs is well established. In the present paper, we will mainly review the roles of $\beta$-arrestins in $\beta A R$ mediated signaling in normal and HF conditions, their function 
in the heart, and their potential as therapeutic target for HF treatment.

\section{$\beta$-ARRESTIN FAMILY AND STRUCTURE}

The arrestin family consists of four members. Arrestin1 and arrestin4 (known as visual arrestin, and cone arrestin, respectively) are expressed in the rods and cones of eyes, respectively. The $\beta$-arrestin 1 and $\beta$-arrestin2 (known as arrestin2 and arrestin3, respectively) are abundantly expressed throughout mammalian tissues (Gurevich and Gurevich, 2004). Arrestin contains an $\mathrm{N}$-domain and a $\mathrm{C}$-domain, each consisting of seven stranded $\beta$-sheets, linked through a short linker region (Graznin et al., 1998; Hirsch et al., 1999).

The $\mathrm{N}$-domain of arrestins contains a recognition region for activated receptors and the C-domain contains a secondary receptor recognition region (Gurevich et al., 1995). The phosphate sensor region is located in the linker between $\mathrm{N}$-domain and $\mathrm{C}$-domain and forms part of the hydrophilic core of arrestins. The interaction between the end of C-domain and the phosphate sensor region maintains the arrestin structure in the resting state. In the active state, this interaction is disrupted upon receptor binding, allowing arrestin to bind the phosphorylated receptor with a high affinity (Gurevich and Gurevich, 2004).

\section{ROLE OF $\beta$-ARRESTIN IN $\beta$ AR DESENSITIZATION}

Agonist binding to $\beta$ AR promotes receptor coupling with heterotrimeric $G$ proteins and triggers the dissociation into activated $\mathrm{G} \alpha_{s}$ and the $\mathrm{G} \beta \gamma$ subunits, which stimulates adenylyl cyclase (AC) and increases cAMP levels. cAMP binds to and interacts with its downstream effectors, resulting in activation of cAMP signal transduction. Subsequent to agonist binding, activated $\beta$ ARs are phosphorylated by GRKs leading to recruitment of $\beta$-arrestins and inhibition of further interaction of receptor with $\mathrm{G}$ proteins. This process is known as "receptor desensitization" as described previously (Ferguson, 2001; Luttrell and Lefkowitz, 2002).

\section{ROLE OF $\beta$-ARRESTIN IN $\beta$ AR TRAFFICKING}

In addition to their regulation of $\beta A R$ desensitization, $\beta$-arrestins are essential for $\beta A R$ trafficking to intracellular compartments located in the cytosol. This process is called " $\beta A R$ internalization." Currently, $\beta$-arrestins are reported to interact with regulatory proteins required for receptor internalization, including clathrin, AP-2, guanine-nucleotide exchange factors, phosphoinositides, and GTPase activating proteins (reviewed in DeWire et al., 2007). After their internalization, $\beta$ ARs are directed toward two main intracellular pathways either degradation or recycling (Tan et al., 2004). The $\beta$ ARs targeted for recycling are transported to early endosomes where the receptors are dephosphorylated by protein phosphatase 2A (PP2A) (known as $\beta A R$ dephosphorylation) before being transported back to the plasma membrane. Dephosphorylation of $\beta$ ARs is dependent on the acidification in early endosomes because acidification enhances PP2A catalytic function (Krueger et al., 1997). The $\beta$ ARs targeted for degradation are transferred to lysosomes where they are eventually degraded via ubiquitination mediated degradation (Tan et al., 2004). Both GRK-mediated receptor phosphorylation and $\beta$-arrestin binding to $\beta_{2}$ ARs are necessary for $\beta_{2} A R$ ubiquitination (Shenoy et al., 2001). However, the role of $\beta$-arrestin mediated $\beta$ ARs targeting for recycling and degradation is poorly understood.

\section{$\beta$-ARRESTIN ACTS AS SCAFFOLDING PROTEINS}

In addition to their roles in receptor desensitization and internalization, $\beta$-arrestins are recognized as multifunctional scaffolding proteins that work as adaptor proteins linking receptors to several downstream effectors such as ERK1/2 (Luttrell et al., 2001; Shenoy et al., 2006), JNK (McDonald et al., 2000), Src (Luttrell et al., 1999), and calmodulin (Wu et al., 2006). $\beta$-Arrestins are also known to bind to and activate CaMKII following $\beta_{1} \mathrm{AR}$ stimulation (Mangmool et al., 2010). Interestingly, proteomic analysis by mass spectrometry demonstrated that $\beta$-arrestins bind to and interact with various types of proteins that play roles in cellular signaling (Xiao et al., 2007). Their abilities to form multifunctional protein complexes are related to functionally selective responses. $\beta$-arrestins play an essential role in the CaMKII signaling responsible for cardiac hypertrophy and HF. Stimulation of $\beta_{1}$ AR promotes a conformational change in $\beta$-arrestin which then induces the formation of a stable complex, including $\beta$-arrestin, CaMKII, and cAMP-dependent guanine-nucleotide exchange factor (Epac) (Mangmool et al., 2010). The role of $\beta$-arrestin in this multiprotein complex consists of holding Epac and CaMKII in structural proximity to activate CaMKII signaling (Mangmool et al., 2010). Discovering the mechanism of multifunctional complex formation by $\beta$-arrestins will help to understand the physiological importance of this scaffolding protein complex in HF.

\section{ROLE OF $\beta$-ARRESTINS IN THE FAILING HEART}

Downregulation and desensitization of $\beta$ ARs occur in the failing heart, leading to dramatically diminish cardiac functions via reduced contractility (Brodde, 1993; Port and Bristow, 2001). The modulation mechanism of $\beta$ ARs is elucidated at the molecular level and involves GRKs and $\beta$-arrestins. Two isoforms of $\beta$-arrestin are expressed in the heart, namely $\beta$-arrestin1 and $\beta$-arrestin2 (Ungerer et al., 1994). The signaling mediated by $\beta$-arrestins independently to classical $G$ protein-mediated signaling may be associated with cardioprotective effects (Patel 
et al., 2009; Noor et al., 2011). However, the specific roles of each $\beta$-arrestin isoform in cardiac $\beta A R$ dysfunction, leading to the pathophysiology of HF are not fully understood.

\section{CARDIOPROTECTIVE EFFECTS OF $\beta$-ARRESTINS}

McCrink et al. (2017) have demonstrated that overexpression of $\beta$-arrestin2 in mice restores inotropic reserves of $\beta$-adrenergic regulation. They have shown that $\beta$-arrestin 2 directly binds to and activates sarcoplasmic/endoplasmic reticulum $\mathrm{Ca}^{2+}$-ATPase 2a (SERCA2a), a key regulator of $\beta_{1}$ AR-dependent cardiac contractility. The association of $\beta$-arrestin2 with SERCA2a contributes to SERCA2a SUMO (small ubiquitin-like modifier)ylation and then increases SERCA2a activity, leading to increased cardiac contractility (McCrink et al., 2017). In contrast, $\beta$-arrestin1 had no effect on SERCA2a activation.

Although $\beta$-arrestin 2 expression is low in the mammalian heart, including humans (Ungerer et al., 1994), $\beta$-arrestin2 has cardioprotective roles against HF. Thus, cardiac-specific $\beta$-arrestin2 gene transfer is a very attractive approach for gene therapy in HF patients. Another approach to treatment of HF is selective activation of $\beta$-arrestin2, although the expression level of $\beta$-arrestin2 is low in the heart. TRV120067 is a $\beta$-arrestinbiased ligand targeted to the angiotensin II type 1 receptor $\left(\mathrm{AT}_{1} \mathrm{R}\right)$ that works similar to ARBs for selective blockade of Ang II binding to $\mathrm{AT}_{1} \mathrm{R}$ and subsequent $\mathrm{G}$ protein coupling, while simultaneously and preferentially activates $\beta$-arrestin2dependent signaling. TRV120067 exhibits cardioprotective effects in a mouse model with dilated cardiomyopathy (Ryba et al., 2017), suggesting that $\beta$-arrestin2-dependent signaling confers significant benefits on cardiac function and structure. $\beta$-Arrestin2 constitutively localizes in cardiac sarcomeres, and the localization is enhanced by TRV120067 that activates $\beta$-arrestin2 and the downstream effector SERCA2a (Ryba et al., 2017).

Many studies have demonstrated that excessive inflammation induces detrimental effects on the heart after MI. Because inflammatory cytokines are reported to induce cardiomyocyte apoptosis (Ing et al., 1999; Li et al., 2007), it is possible that they enhance apoptosis in the infarct area. However, inflammation is also reported to be necessary for recovery of the heart from MI-induced injury. Monocyte subsets phagocytose dead cells and produce anti-inflammatory cytokines such as TGF- $\beta$ (Frangogiannis, 2008). TGF- $\beta$ plays a crucial role in cardiac repair by suppressing inflammation and promotes differentiation of fibroblasts into myofibroblasts that produce extracellular matrix. Although many reports on the roles of inflammation in MI, it has not been established whether inhibition or enhancement of inflammation is protective against MI-induced cardiac dysfunction and remodeling in clinical practice.

Among GRKs and $\beta$-arrestins, $\beta$-arrestin2 is an interesting target for the treatment of HF. $\beta$-Arrestin2 delays inflammatory responses by interfering with macrophage recruitment to the infarcted area. $\beta$-Arrestin 2 is highly expressed in infiltrated macrophages, resulting in the inhibition of excessive inflammation and apoptosis after MI (Watari et al., 2013). The level of many inflammatory cytokines was higher in $\beta$-arrestin 2 KO mice than in wild-type (WT) mice after MI, showing that $\beta$-arrestin2 has a protective role in inflammatory processes induced by MI. Moreover, the mortality rate of $\beta$-arrestin2 KO mice was increased (Watari et al., 2013). Furthermore, $\beta$-arrestin2 has been shown to prevent cell apoptosis (Ahn et al., 2009; Yang et al., 2012). These results indicate that $\beta$-arrestin2 in infiltrated macrophages plays an essential role in the inhibition of excessive inflammation after MI, and inhibition of $\beta$-arrestin2 function prevents myocyte apoptosis against ischemic injury. Several studies have shown the importance of $\beta$-arrestin2-mediated signal transduction in the heart; in particular, $\beta$-arrestin 2 protects the heart against overstimulation of $\beta \mathrm{AR}$ in in vitro and in vivo studies (Noma et al., 2007). Therefore, pharmacological activation of $\beta$-arrestin2 might represent a beneficial therapy in HF.

It has been reported that $\beta_{1} \mathrm{AR}$ (Noma et al., 2007) and $\beta_{2} \mathrm{AR}$ (Shenoy et al., 2006) mediate ERK1/2 signaling in a $\beta$-arrestin-dependent manner. Stimulation of $\beta_{1} \mathrm{AR}$ results in transactivation of EGFR, which activates ERK signaling (Noma et al., 2007). EGFR transactivation following $\beta A R$ stimulation is mediated by a GRK-dependent and $\beta$-arrestindependent pathway, which exhibits cardioprotective effects under conditions of excessive catecholamine stimulation (Noma et al., 2007). These results also suggest that the effects of $G$ protein-mediated signaling may contribute to the detrimental cardiac remodeling observed during $\beta_{1} \mathrm{AR}$ overactivation.

A model of $\beta_{1} A R$ signaling in the heart has been proposed, in which $\beta_{1}$ AR mediates two distinct signaling pathways following receptor stimulation (Noma et al., 2007). The G proteindependent signaling might be harmful and cause detrimental effects under excessive catecholamine stimulation, whereas $\beta$-arrestin-mediated signaling that is able to transactivate EGFR to evoke cardioprotective effects in response to the same pathological stimuli in the heart (Noma et al., 2007). Although EGFR activation results in cardiac hypertrophy, whether $\beta$-arrestin-mediated transactivation of EGFR is associated with cardiac hypertrophy is unknown.

\section{$\beta$-ARRESTIN1 HAS DETRIMENTAL EFFECTS TO THE HEART}

The role of $\beta$-arrestin1 in remodeling of post-MI has been investigated by using $\beta$-arrestin1-knockout (-KO) mice and WT mice under normal conditions and after surgical MI operation (Bathgate-Siryk et al., 2014). Normal (sham-operated) $\beta$-arrestin1-KO mice display enhanced $\beta$ AR-dependent contractility due to impairment of $\beta A R$ desensitization. After MI, $\beta$-arrestin1-KO mice display enhanced overall cardiac function (and $\beta A R$-dependent contractility) compared to WT mice. $\beta$-Arrestin1-KO mice also show increased survival, and decreased cardiac infarct size, apoptosis, and adverse remodeling, as well as circulating catecholamines and aldosterone, compared to WT mice after MI. The underlying mechanisms are; (1) on one 
hand improved cardiac $\beta A R$ signaling and function, as evidenced by increased $\beta \mathrm{AR}$ density and pro-contractile signaling, via reduced cardiac $\beta$ AR desensitization due to cardiac $\beta$-arrestin 1 absence, and (2) on the other hand decreased production leading to lower circulating levels of catecholamines and aldosterone due to adrenal $\beta$-arrestin 1 absence. Thus, $\beta$-arrestin1, via both cardiac and adrenal effects, is detrimental for cardiac structure and function and significantly exacerbates development of HF after MI. Thus, $\beta$-arrestin1 might be an important negative regulator of $\beta$ AR-mediated cardiac signaling and functions through the classical processes of $\beta A R$ desensitization and downregulation. $\beta$-Arrestin 1 may be a salient $\beta$-arrestin isoform that is responsible for $\beta \mathrm{AR}$ desensitization and downregulation in the heart, leading to progression of cardiac abnormality and dysfunction. In contrast, stimulation of $\beta$-arrestin 2 through $\beta A R$ leads to EGFR transactivation and ERK1/2 activation that promotes cell survival and proliferation. Thus, the actions of two isoforms of $\beta$-arrestin ( $\beta$-arrestin1 and $\beta$-arrestin 2$)$ might counteract each other in certain cells and tissues, including in the heart (Rajagopal et al., 2006; Kim et al., 2008). It also suggests that inhibition of $\beta$-arrestin1 function in the heart by either a specific inhibitor or via genetic manipulation has beneficial effects on HF. However, the underlying mechanisms and actions of each $\beta$-arrestin in desensitization and downregulation of $\beta A R$, and in $G$ protein-independent signaling remain to be clarified.

\section{$\beta$-ARRESTIN-BIASED LIGANDS FOR $\beta$ AR}

The $\beta A R$ antagonist is a ligand that binds to $\beta$ AR but cannot activate the receptor. It also has the ability to antagonize agonist-stimulated $\beta$ AR. However, the concept of agonist and antagonist is challenged by the findings that ligands for $\beta$ ARs could be an antagonist for the $G$ protein-mediated signaling and also act as agonists for the $\beta$-arrestin-mediated signal transduction (Wisler et al., 2007; Kim et al., 2008; Wisler et al., 2014). When a ligand selectively activates one of the $G$ protein-dependent and $\beta$-arrestin-dependent signaling pathway, the ligand is called as "biased ligand." Thus, a $\beta$-arrestinbiased ligand is a ligand that can antagonize the receptormediated $G$ protein activation and at the same time activate signaling pathways in a $G$ protein-independent but $\beta$-arrestindependent manner (Violin and Lefkowitz, 2007). $\beta$-Arrestinbiased ligands are expected to have beneficial effects on $\mathrm{HF}$ because of their selective activation of $\beta$-arrestin signaling that mediates favorable physiological responses in the heart (Noor et al., 2011). Discovery of novel biased ligands for $\beta$ ARs that are able to block $G$ protein-mediated signaling but stimulate $\beta$-arrestin-mediated signaling represents potential therapeutic treatment for HF.

A $\beta$-arrestin-biased ligand is believed to activate an alternative signaling pathway due to the stabilization of the receptor in a particular distinct conformation, resulting in the biased activation of $\mathrm{G}$ protein- or $\beta$-arrestin-dependent signaling. In contrast, unbiased ligand for $\beta A R$ (e.g., isoprenaline) binds to and stabilizes the $\beta \mathrm{AR}$ conformation that equally activates $\mathrm{G}$ protein and $\beta$-arrestin (Rajagopal et al., 2010; Wisler et al., 2014; Bologna et al., 2017). We will mainly summarize here the beneficial effects of $\beta$-arrestin-biased ligands for $\beta A R$.

Long-term use of $\beta$-blockers clinically delays progression of $\mathrm{HF}$ by reducing cardiac remodeling and correcting left ventricular contractility in the failing heart (López-Sendón et al., 2004). $\beta$-Blockers may regulate the $\beta$ AR system by modulating $\beta_{1} \mathrm{AR}$ functions and reversing receptor sensitivity. Moreover, administration of $\beta$-blockers has been reported to increase $\beta A R$ responsiveness and decrease GRK2 expression (Iaccarino et al., $1998 b)$, contributing to the sensitization of $\beta A R$ functions and signaling. Nevertheless, each $\beta$-blocker shows a unique effect on $\beta$ AR-mediated signaling. $\beta$-Blockers differ in terms of $\beta A R$ subtype selectivity, ability to block $\alpha A R$, antioxidant activity, and anti-inflammatory activity (Barrese and Taglialatela, 2013). Some $\beta$-blockers are $\beta$-arrestin-biased ligands, including carvedilol, metoprolol, and nebivolol.

\section{INTERACTION OF $\beta$-ARRESTIN-BIASED LIGAND WITH $\beta A R$}

The binding of agonists and antagonists can evoke differential conformational changes of $\beta$ ARs. Biased ligands (or biased agonist) can induce distinct $\beta \mathrm{AR}$ conformations that selectively activate specific signaling pathways, different from full agonists and antagonists (Thanawala et al., 2014). $\beta$-Arrestin-biased ligands induce and stabilize a ligand-dependent unique receptor conformation and then selectively activate the particular signaling pathway (Thanawala et al., 2014; McCorvy et al., 2018). Stimulation of vasopressin type 2 receptor (V2R) by a $G$ protein-biased ligand stabilizes $V 2 R$ in a conformation different from that stabilized by a $\beta$-arrestin-biased ligand (Rahmeh et al., 2012). In particular, the third intracellular loop and transmembrane domain 6 (TM6) regions of V2R are necessary for $G$ protein-mediated signaling, whereas the TM7 and putative helix 8 are required for $\beta$-arrestinmediated signaling (Rahmeh et al., 2012). Thus, the functional outcome of biased ligands depends on which ligands stabilized conformation is favorable for $G$ protein- or $\beta$-arrestincoupling.

In addition, site-specific fluorine-19 nuclear magnetic resonance (19F-NMR) of $\beta_{2} \mathrm{AR}$ has shown that ligand binding to $\beta_{2} \mathrm{AR}$ modulates $\mathrm{G}$ protein- and $\beta$-arrestin-dependent signaling by inducing distinct conformations of the receptor depending on stimulation with either unbiased or biased ligands (Liu et al., 2012). Unbiased ligands bind to $\beta_{2} \mathrm{AR}$ and induce the conformational change of helix 6 into the active state that specifically leads to activate $G$ protein signaling. In contrast, $\beta$-arrestin-biased ligands predominantly induce the conformational change of helix 7 of $\beta_{2} \mathrm{AR}$ that is necessary for $\beta$-arrestin-mediated signal transduction (Liu et al., 2012). Moreover, the tyrosine residue at position 308 (Tyr-308) of $\beta_{2} A R$ is found to be essential for Gs proteinbiased signaling of $\beta_{2} \mathrm{AR}$. The unique interaction between ligand and Tyr-308 of TM7 in $\beta_{2} \mathrm{AR}$ stabilizes the receptor conformation favoring the $\beta_{2}$ AR-Gs protein coupling that 
is necessary for G protein-dependent signaling (Woo et al., 2014).

Roth's group has reported that ligand binding to amino acid residues at TM5 and extracellular loop 2 (ECL2) of the receptor are important for $\mathrm{Gi} / \mathrm{o}$ protein and $\beta$-arrestin signaling, respectively (McCorvy et al., 2018). They targeted these residues to develop both $G$ protein- and $\beta$-arrestinbiased ligands for aminergic GPCRs that contain similar residues at TM5 and ECL2, including $\beta$ ARs. Ligand contacts with TM5 of GPCR trigger the conformational change to induce a cytoplasmic inward movement of TM5 (Warne and Tate, 2013). This movement change then results in movement of ICL2 and TM6 regions that are involved in G protein coupling and activation (Deupi and Standfuss, 2011; Rasmussen et al., 2011). In contrast, the interaction of biased ligand with ECL2 of $\beta_{2} \mathrm{AR}$ is key for $\beta$-arrestin recruitment. ECL2 is an important region that locks the ligand into the binding site, resulting in an increased period of ligand binding and promotion of $\beta$-arrestin recruitment required for $\beta$-arrestinmediated signaling pathway. Thus, TM5 and ECL2 are the regions to be focused on to develop specific biased ligands (G protein-biased and $\beta$-arrestin-biased ligands) of $\beta$ ARs that possess desirable therapeutic effects with minimal adverse effects.

Lefkowitz's group has used bioluminescence resonance energy transfer-based biosensor of $\beta$-arrestin2 to detect the $\beta$-arrestin conformational change upon biased ligand binding to receptor (Shukla et al., 2008). Their study showed that $\beta$-arrestin can convert $\beta A R$ into multiple conformations and each unique $\beta$-arrestin-favorable conformation can form a complex with different binding proteins and evoke a corresponding specific signal transduction. Although these studies have demonstrated molecular mechanisms and interactions of biased ligand with specific regions of the receptor, further studies are required to establish the effects of $\beta$-arrestin-biased ligands in cellular functions in normal and pathophysiological conditions such as HF.

$\beta$ ARs can modulate the contractile function of the heart. Catecholamines, such as adrenaline and noradrenaline, activate cardiac $\beta_{1} \mathrm{AR}$ and $\beta_{2} \mathrm{AR}$, which then activates the canonical Gs/AC/cAMP signaling cascade. Cyclic AMP binds to and activates its downstream effectors, including PKA (Salazar et al., 2007). PKA phosphorylates a set of regulatory proteins that are essential for cardiac contractility such as the voltage-gated L-type $\mathrm{Ca}^{2+}$ channel, the cardiac ryanodine receptor, phospholamban, and some myofilament components (troponin I and troponin C) (Salazar et al., 2007). PKA mediates phosphorylation and activation of L-type $\mathrm{Ca}^{2+}$ channel and ryanodine receptor results in significant increase in intracellular $\mathrm{Ca}^{2+}$ levels, which is necessary for cardiac muscle contraction. Furthermore, $\beta$ ARmediated phosphorylation of phospholamban (Sulakhe and Vo, 1995), a negative modulator of SERCA, accelerates $\mathrm{Ca}^{2+}$ reuptake into the sarcoplasmic reticulum (SR), and increases $\mathrm{SR} \mathrm{Ca}^{2+}$ stores available for the next contraction (Brittsan and Kranias, 2000). In addition, troponin I phosphorylation by PKA reduces myofilament sensitivity to $\mathrm{Ca}^{2+}$ following BAR stimulation (Endoh and Blinks, 1988), hence inhibiting contractile signaling and accelerating cardiac relaxation (Zhang et al., 1995). Some $\beta$-blockers act as $\beta$-arrestin-biased ligands that can inhibit classical Gs protein signaling and stimulate $\beta$-arrestin signaling. The ability to activate biased signaling may explain the clinical differences between treatment with classical $\beta$-blockers and $\beta$-arrestin-biased $\beta$-blockers. We summarize below recent advances on $\beta$-arrestin-biased $\beta$-blockers that are used in clinic for the treatment of HF as presented in Table 3.

\section{CARVEDILOL}

Carvedilol is a nonselective $\beta$-blocker that can antagonize both $\beta_{1}$ - and $\beta_{2}$-AR. Blockade of $\beta$ ARs in the heart by carvedilol improves cardiac function, including contractility, and attenuates myocardial remodeling in the failing heart (Iaccarino et al., 1998b; Kukin et al., 1999). In addition to nonselective blockade of $\beta A R$, carvedilol has other characteristics, including $\alpha_{1}$-adrenergic blockade, antioxidant, anti-proliferative, anti-inflammatory, and vasodilating effects, which may explain why its efficacy is higher than other $\beta$-blockers (Metra et al., 2005; Pedersen and Cockcroft, 2007; Barrese and Taglialatela, 2013). Interestingly, carvedilol has been classified as a $\beta$-arrestin-biased ligand for $\beta$ ARs (Wisler et al., 2007; Kim et al., 2008).

Among the 16 available $\beta$-blockers, carvedilol is the only $\beta$-blocker that can activate ERK signaling pathway by a $\beta_{2}$ ARmediated, $G$ protein-independent, and $\beta$-arrestin-dependent mechanism (Wisler et al., 2007). Alprenolol and carvedilol can activate the $\beta_{1}$ AR-stimulated transactivation of EGFR through $\beta$-arrestin-mediated signaling without activation of $G$ proteins (Kim et al., 2008). Therefore, carvedilol is different from other $\beta$-blockers, as it acts as a $\beta$-arrestin-biased ligand that exhibits cardioprotective effects in in vitro and in vivo studies (Table 3). Carvedilol-mediated $\beta$-arrestin-biased signaling might contribute to its clinical profile.

On the basis of studies of receptor structure, carvedilol can stabilize divergent receptor conformations and induce phosphorylation of $\beta A R$. The phosphorylation sites of $\beta A R$ by carvedilol are different from those of unbiased ligands (Nobles et al., 2011; Liu et al., 2012). In a meta-analysis, carvedilol has been reported to have superior beneficial effects compared with other $\beta_{1}$-selective $\beta$-blockers (i.e., atenolol and bisoprolol) in post-MI (DiNicolantonio et al., 2013). Carvedilol has more potent effects on the reduction of mortality and morbidity in acute MI and HF compared with other $\beta$-blockers in randomized comparison trials (DiNicolantonio et al., 2013). The beneficial effects of carvedilol might be due to the activation of $\beta$-arrestinmediated transactivation of EGFR that exhibits cardioprotective effects (Noma et al., 2007). These findings show that $\beta$-arrestinbiased $\beta$-blocker may provide an increased therapeutic benefit compared with unbiased $\beta$-blockers.

\section{METOPROLOL}

Metoprolol is reported as a biased ligand that specifically induces a $G$ protein-independent and GRK5/ $\beta$-arrestin2-dependent 
TABLE 3 | Effects of $\beta$-arrestin-biased $\beta$-blockers.

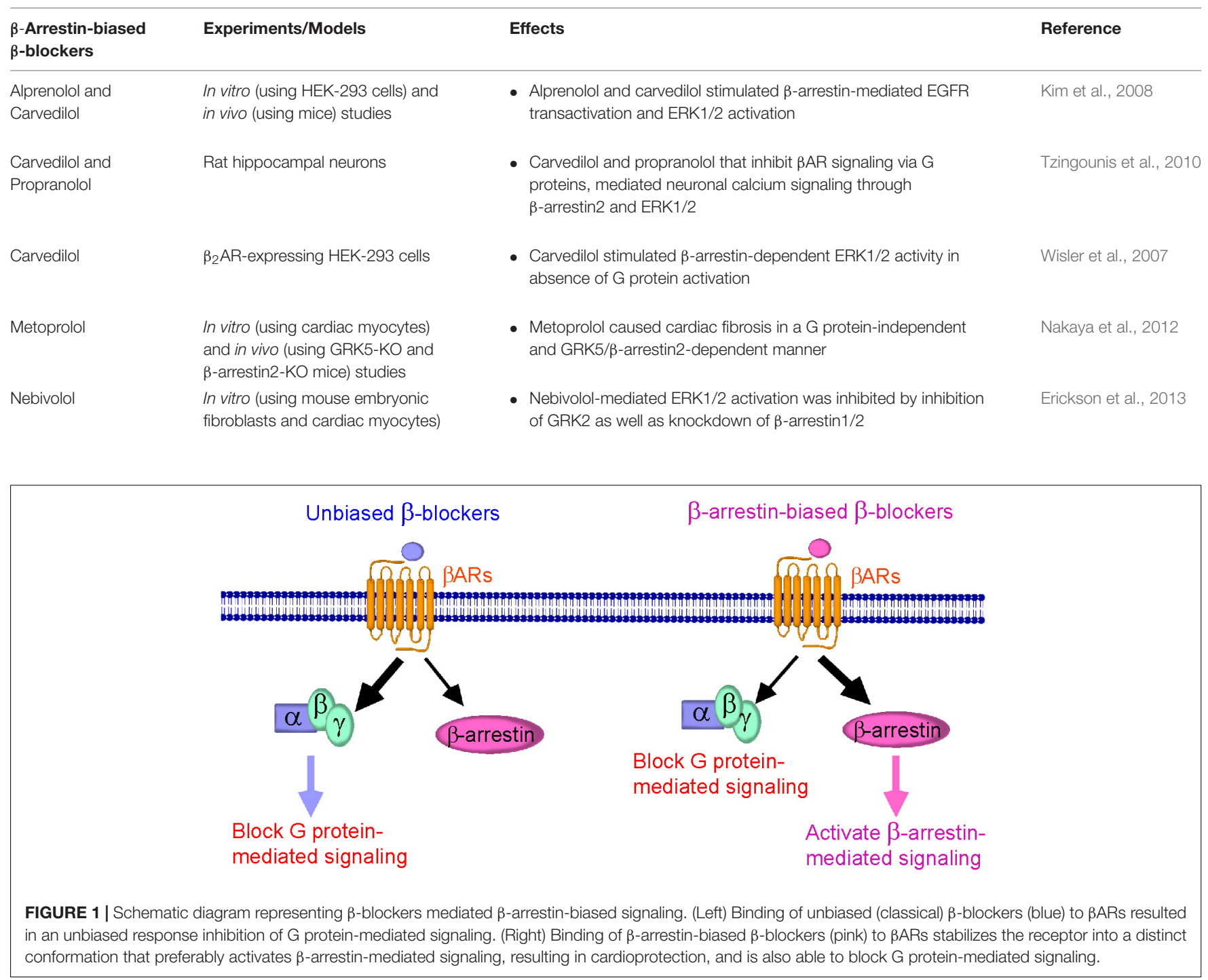

pathway (Nakaya et al., 2012). Besides receptor regulation, GRKs and $\beta$-arrestins have roles in the modulation of cellular signaling via $\beta$ ARs independently of $G$ protein activation. While carvedilol (Wisler et al., 2007; Tzingounis et al., 2010) and alprenolol (Kim et al., 2008) activate intracellular signaling through $\beta$ ARs in the $\beta$-arrestin-dependent manner (Table 3 ). In addition, carvedilol and alprenolol are able to transactivate EGFR, resulting in ERK1/2 activation, whereas metoprolol does not (Nakaya et al., 2012). Administration of metoprolol to mice induced cardiac fibrosis, resulting in a decrease of diastolic function (Nakaya et al., 2012). This fibrotic pathway is mediated through the $\beta_{1} A R$, which is dependent on $\beta$-arrestin 2 and GRK5 and is unrelated to $G$ protein action (Table 3). Moreover, metoprolol increases the expression of profibrotic factors, leading to the activation of cardiac fibroblasts, eventually inducing fibrosis (Nakaya et al., 2012).

GRK5, but not GRK6, is necessary for the G proteinindependent and $\beta$-arrestin2-dependent cardiac fibrosis by metoprolol. Different GRK isoforms phosphorylate distinct sites of $\beta A R$ to initiate $\beta$-arrestin-biased signaling (Violin et al., 2006). For example, inhibition of GRK5 or GRK6 attenuates $\beta$-arrestin-mediated ERK1/2 activation following $\beta_{1}$ AR stimulation. Phosphorylation of $\beta_{1}$ AR is not affected by inhibition of GRK2 or GRK3 (Noma et al., 2007; Kim et al., 2008). Therefore, phosphorylation of $\beta$ ARs by different GRK isoforms together with $\beta$-arrestin binding is crucial in initiating receptor signaling toward $\mathrm{G}$ protein-dependent and $\beta$-arrestindependent signal transductions. Although metoprolol causes cardiac fibrosis, it remains useful in the management of HF patients (Kukin et al., 1999) since metoprolol attenuates the effect of catecholamine overstimulation in the patients' hearts and metoprolol-induced fibrosis is neglectable compared with BAR-induced fibrosis (Nuamnaichati et al., 2018) and HFinduced fibrosis.

Understanding of the cellular signaling pathway of $\beta$-arrestinbiased $\beta$-blockers is important for the development of novel 
$\beta$-blockers that primarily target $\beta$-arrestin-mediated $\beta A R$ signaling with cardioprotective effects. The discovery of other $\beta$-arrestin-biased $\beta$-blockers (Figure 1) not only provides additional pieces of evidence for their beneficial therapeutic effects, but also helps to design next-generation $\beta$-blockers for HF treatment.

\section{CONCLUSION}

$\beta A R$ desensitization and overstimulation is the pathological hallmark of HF. Although GRKs play an important role in $\beta A R$ desensitization, the involvement of individual GRK isoform in the development of a failing heart is not fully understood. Expression and activity of GRKs, especially GRK2, is significantly increased in the failing heart. Thus, inhibition of GRK activity via $\beta$ ARKct gene therapy, synthetic GRK inhibitors, and small peptide GRK inhibitors, represents promising therapeutic approaches for HF treatment. Although GRK2 inhibitors improve cardiac functions in various animal models of $\mathrm{HF}$, these inhibitors have not yet been tested in clinical studies. $\beta$-Arrestins are also involved in the regulation of cardiac functions in normal and failing heart. However, the specific contribution of each $\beta$-arrestin isoform that plays a role in the development of a failing heart in patients with $\mathrm{HF}$ remains to be clarified. Based on the physiological and pathological functions of GRKs and $\beta$-arrestins in the heart,

\section{REFERENCES}

Agüero, J., Almenar, L., Montó, F., Oliver, E., Sánchez-Lázaro, I., Vicente, D., et al. (2012). Myocardial G protein receptor-coupled kinase expression correlates with functional parameters and clinical severity in advanced heart failure. J. Cardiac. Fail. 18, 53-61. doi: 10.1016/j.cardfail.2011.10.008

Ahn, S., Kim, J., Hara, M. R., Ren, X. R., and Lefkowitz, R. J. (2009). $\beta$-Arrestin-2 mediates anti-apoptotic signaling through regulation of BAD phosphorylation. J. Biol. Chem. 284, 8855-8865. doi: 10.1074/jbc.M80846 3200

Andersen, M. J., and Borlaug, B. A. (2014). Heart failure with preserved ejection fraction: current understanding and challenges. Curr. Cardiol. Rep. 16:501. doi: 10.1007/s11886-014-0501-8

Anis, Y., Leshem, O., Reuveni, H., Wexler, I., Ben Sasson, R., Yahalom, B., et al. (2004). Antidiabetic effect of novel modulating peptides of G-protein-coupled kinase in experimental models of diabetes. Diabetologia 47, 1232-1244. doi: 10.1007/s00125-004-1444-1

Barrese, V., and Taglialatela, M. (2013). New advances in beta-blocker therapy in heart failure. Front. Physiol. 4:323. doi: 10.3389/fphys.2013.00323

Barthet, G., Gaven, F., Framery, B., Shinjo, K., Nakamura, T., Claeysen, S., et al. (2005). Uncoupling, and endocytosis of 5-hydroxytryptamine 4 receptors. Distinct molecular events with different GRK2 requirements. J. Biol. Chem. 280, 27924-27934. doi: 10.1074/jbc.M502272200

Bathgate-Siryk, A., Dabul, S., Pandya, K., Walklett, K., Rengo, G., Cannavo, A., et al. (2014). Negative impact of $\beta$-arrestin-1 on post-myocardial infarction heart failure via cardiac and adrenal-dependent neurohormonal mechanisms. Hypertension 63, 404-412. doi: 10.1161/HYPERTENSIONAHA.113. 02043

Benovic, J. L., Onorato, J., Lohse, M. J., Dohlman, H. G., Staniszewski, C., Caron, M. G., et al. (1990). Synthetic peptides of the hamster $\beta 2$ adrenoceptor as substrates and inhibitors of the $\beta$-adrenoceptor kinase. Br. J. Clin. Pharmacol. 30, 3S-12S. doi: 10.1111/j.1365-2125.1990.tb 05462.x both could be candidates for novel theranostic strategies for HF treatment. Cavedilol, alprenolol, and nebivolol are identified as $\beta$-arrestin-biased $\beta$-blockers that are able to activate $\beta$-arrestinmediated signaling while blocking $G$ protein-mediated signaling, providing cardioprotection. These $\beta$-arrestin-biased $\beta$-blockers may exhibit distinct pharmacological effects relative to their unbiased counterparts; however, the clinical outcome of these $\beta$-blockers remains to be elucidated. Elucidation of the signaling mechanisms of $\beta$-arrestin-biased $\beta$-blockers will facilitate our understanding and could lead to the discovery of new $\beta$-blockers with fewer side effects while providing effective therapy for HF patients.

\section{AUTHOR CONTRIBUTIONS}

SM and WP mainly wrote the manuscript. HK edited this manuscript.

\section{FUNDING}

This work was supported in part by grants from JSPS KAKENHI Grant No. JP17H01525 and the National Research Foundation of Korea (NRF) grants funded by the Korea Government (MSIP; 2017K1A1A2004511; to HK), and Thailand Research Fund (Grant RSA6080061; to SM).

Bologna, Z., Teoh, J. P., Bayoumi, A. S., Tang, Y., and Kim, I. M. (2017). Biased G protein-coupled receptor signaling: new player in modulating physiology and pathology. Biomol. Ther. 25, 12-25. doi: 10.4062/biomolther.2016.165

Bonsu, K. O., Arunmanakul, P., and Chaiyakunapruk, N. (2018). Pharmacological treatments for heart failure with preserved ejection fraction - a systemic review and indirect comparison. Heart Fail. Rev. 23, 147-156. doi: 10.1007/s10741018-9679-y

Bouvier, M., Hausdorff, W. P., De Blasi, A., O’Dowd, B. F., Kobilka, B. K., Caron, M. G., et al. (1988). Removal of phosphorylation sites from the $\beta 2$-adrenergic receptor delays the onset of agonist-promoted desensitization. Nature 333, 370-373. doi: 10.1038/333370a0

Brittsan, A. G., and Kranias, E. G. (2000). Phospholamban and cardiac contractile function. J. Mol. Cell. Cardiol. 32, 2131-2139. doi: 10.1006/jmcc.2000.1270

Brodde, O. E. (1993). Beta-adrenoceptors in cardiac disease. Pharmacol. Ther. 60, 405-430. doi: 10.1016/0163-7258(93)90030-H

Choi, D. J., Koch, W. J., Hunter, J. J., and Rockman, H. A. (1997). Mechanism of $\beta$-adrenergic receptor desensitization in cardiac hypertrophy is increased $\beta$-adrenergic receptor kinase. J. Biol. Chem. 272, 17223-17229. doi: 10.1074/jbc. 272.27.17223

Ciccarelli, M., Chuprun, J. K., Rengo, G., Gao, E., Wei, Z., Peroutka, R. J., et al. (2011). G protein-coupled receptor kinase 2 activity impairs cardiac glucose uptake and promotes insulin resistance after myocardial ischemia. Circulation 123, 1953-1962. doi: 10.1161/CIRCULATIONAHA.110.988642

Cipolletta, E., Campanile, A., Santulli, G., Sanzari, E., Leosco, D., Campiglia, P., et al. (2009). The $\mathrm{G}$ protein coupled receptor kinase 2 plays an essential role in beta-adrenergic receptor-induced insulin resistance. Cardiovasc. Res. 84, 407-415. doi: 10.1093/cvr/cvp252

de Lucia, C., Eguchi, A., and Koch, W. J. (2018). New insights in cardiac $\beta$-adrenergic signaling during heart failure and aging. Front. Pharmacol. 9:904. doi: 10.3389/fphar.2018.00904

Deupi, X., and Standfuss, J. (2011). Structural insights into agonist-induced activation of G-protein-coupled receptors. Curr. Opin. Struct. Biol. 21, 541-551. doi: 10.1016/j.sbi.2011.06.002 
DeWire, S. M., Ahn, S., Lefkowitz, R. J., and Shenoy, S. K. (2007). $\beta$-Arrestins and cell signaling. Annu. Rev. Physiol. 69, 483-510. doi: 10.1146/annurev.physiol.69. 022405.154749

DiNicolantonio, J. J., Lavie, C. J., Fares, H., Menezes, A. R., and O'Keefe, J. H. (2013). Meta-analysis of carvedilol versus beta 1 selective beta-blockers (atenolol, bisoprolol, metoprolol, and nebivolol). Am. J. Cardiol. 111, 765-769. doi: 10.1016/j.amjcard.2012.11.031

Dzimiri, N., Muiya, P., Andres, E., and Al-Halees, Z. (2004). Differential functional expression of human myocardial $G$ protein receptor kinases in left ventricular cardiac diseases. Eur. J. Pharmacol. 489, 167-177. doi: 10.1016/j.ejphar.2004.03. 015

Eichmann, T., Lorenz, K., Hoffmann, M., Brockmann, J., Krasel, C., Lohse, M. J., et al. (2003). The amino-terminal domain of G-protein-coupled receptor kinase 2 is a regulatory G $\beta \gamma$ binding site. J. Biol. Chem. 278, 8052-8057. doi: 10.1074/ jbc.M204795200

Endoh, M., and Blinks, J. R. (1988). Actions of sympathomimetic amines on the $\mathrm{Ca}^{2+}$ transients and contractions of rabbit myocardium: reciprocal changes in myofibrillar responsiveness to $\mathrm{Ca}^{2+}$ mediates through $\alpha$ - and $\beta$-adrenoceptors. Circ. Res. 62, 247-265. doi: 10.1161/01.RES.62.2.247

Erickson, C. E., Gul, R., Blessing, C. P., Nguyen, J., Liu, T., Pulakat, L., et al. (2013). The $\beta$-blocker nebivolol is a GRK/ $\beta$-arrestin biased agonist. PLoS One 8:e71980. doi: 10.1371/journal.pone.0071980

Ferguson, S. S. G. (2001). Evolving concepts in G protein-coupled receptor endocytosis: the role in receptor desensitization and signaling. Pharmacol. Rev. $53,1-24$.

Frangogiannis, N. G. (2008). The immune system and cardiac repair. Pharmacol. Res. 58, 88-111. doi: 10.1016/j.phrs.2008.06.007

Fredericks, Z. L., Pitcher, J. A., and Lefkowitz, R. J. (1996). Identification of the $\mathrm{G}$ protein-coupled receptor kinase phosphorylation sites in the human beta2adrenergic receptor. J. Biol. Chem. 271, 13796-13803. doi: 10.1074/jbc.271.23. 13796

Gainetdinov, R. R., Bohn, L. M., Walker, J. K., Laporte, S. A., Macrae, A. D., Caron, M. G., et al. (1999). Muscarinic supersensitivity and impaired receptor desensitization in $\mathrm{G}$ protein-coupled receptor kinase 5-deficient mice. Neuron 24, 1029-1036. doi: 10.1016/S0896-6273(00)81048-X

Gold, J. I., Gao, E., Shang, X., Premont, R. T., and Koch, W. J. (2012). Determining the absolute requirement of $\mathrm{G}$ protein-coupled receptor kinase 5 for pathological cardiac hypertrophy: short communication. Circ. Res. 115, 976-985. doi: 10.1161/CIRCRESAHA.112.273367

Graznin, J., Wilden, U., Choe, H. W., Labahn, J., Krafft, B., and Buldt, G. (1998). $\mathrm{X}$-ray crystal structure of arrestin from bovine rod outer segments. Nature 391, 918-921. doi: 10.1038/36147

Gros, R., Benovic, J. L., Tan, C. M., and Feldman, R. D. (1997). G-proteincoupled receptor kinase activity is increased in hypertension. J. Clin. Invest. 99, 2087-2093. doi: 10.1172/JCI119381

Grundmann, M., Merten, N., Malfacini, D., Inoue, A., Preis, P., Simon, K., et al. (2018). Lack of beta-arrestin signaling in the absence of active G proteins. Nat. Commun. 9:341. doi: 10.1038/s41467-017-02661-3

Gurevich, V. V., Dion, S. B., Onorato, J. J., Ptasienski, J., Kim, C. M., SterneMarr, R., et al. (1995). Arrestin interactions with G protein-coupled receptors. Direct binding studies of wild-type and mutant arrestins with rhodopsin, $\beta 2$-adrenergic, and $\mathrm{m} 2$ muscarinic cholinergic receptors. J. Biol. Chem. 270, 720-731. doi: 10.1074/jbc.270.2.720

Gurevich, V. V., and Gurevich, E. V. (2004). The molecular acrobatics of arrestin activation. Trends Pharmacol. Sci. 25, 105-111. doi: 10.1016/j.tips.2003.12.008

Harding, V. B., Jones, L. R., Lefkowitz, R. J., Koch, W. J., and Rockman, H. A. (2001). Cardiac $\beta$ ARK1 inhibition prolongs survival and augments $\beta$-blocker therapy in a mouse model of severe heart failure. Proc. Natl. Acad. Sci. U.S.A. 98, 5809-5814. doi: 10.1073/pnas.091102398

Harris, C. A., Chuang, T. T., and Scorer, C. A. (2001). Expression of GRK2 is increased in the left ventricles of cardiomyopathic hamsters. Basic Res. Cardiol. 96, 364-368. doi: 10.1007/s003950170044

Hata, J. A., Williams, M. L., and Koch, W. J. (2004). Genetic manipulation of myocardial $\beta$-adrenergic receptor activation and desensitization. J. Mol. Cell. Cardiol. 37, 11-21. doi: 10.1016/j.yjmcc.2004.03.014

Hirsch, J. A., Schubert, C., Gurevich, V. V., and Sigler, P. B. (1999). The 2.8 Å crystal structure of visual arrestin: a model for arrestin's regulation. Cell 97, 257-269. doi: 10.1016/S0092-8674(00)80735-7
Homan, K. T., Larimore, K. M., Elkins, J. M., Szklarz, M., Knapp, S., and Tesmer, J. J. (2015). Identification and structure-function analysis of subfamily selective $\mathrm{G}$ protein-coupled receptor kinase inhibitors. ACS Chem. Biol. 10, 310-319. doi: $10.1021 / \mathrm{cb} 5006323$

Homan, K. T., Wu, E., Wilson, M. W., Sigh, P., Larsen, S. D., and Tesmer, J. J. (2014). Structural and functional analysis of $G$ protein-coupled receptor kinase inhibition by paroxetine and a rationally designed analog. Mol. Pharmacol. 85, 237-248. doi: 10.1124/mol.113.089631

Hullmann, J., Traynham, C. J., Coleman, R. C., and Koch, W. J. (2016). The expanding GRK interactome: implications in cardiovascular disease and potential for therapeutic development. Pharmacol. Res. 110, 52-64. doi: 10. 1016/j.phrs.2016.05.008

Iaccarino, G., Rockman, H. A., Shotwell, K. F., Tomhave, E. D., and Koch, W. J. (1998a). Myocardial overexpression of GRK3 in transgenic mice: evidence for in vivo selectivity of GRKs. Am. J. Physiol. 275, H1298-H1306.

Iaccarino, G., Tomhave, E. D., Lefkowitz, R. J., and Koch, W. J. (1998b). Reciprocal in vivo regulation of myocardial $G$ protein-coupled receptor kinase expression by $\beta$-adrenergic receptor stimulation and blockade. Circulation 98, 1783-1789.

Iino, M., Furogori, T., Mori, T., Moriyama, S., Fukuzawa, A., and Shibano, T. (2002). Rational design and evaluation of new lead compound structures for selective BARK1 inhibitors. J. Med. Chem. 45, 2150-2159. doi: 10.1021/ jm010093a

Ing, D. J., Zang, J., Dzau, V. J., Webster, K. A., and Bishopric, N. H. (1999). Modulation of cytokine-induced cardiac myocyte apoptosis by nitric oxide, Bak, and Bcl-x. Circ. Res. 84, 21-33. doi: 10.1161/01.RES.84.1.21

Kim, I. M., Tilley, D. G., Chen, J., Salazar, N. C., Whalen, E. J., Violin, J. D., et al. (2008). $\beta$-blockers alprenolol and carvedilol stimulate $\beta$-arrestin-mediated EGFR transactivation. Proc. Natl. Acad. Sci. U.S.A. 105, 14555-14560. doi: 10.1073/pnas.0804745105

Kobayashi, H., Narita, Y., Nishida, M., and Kurose, H. (2005). Beta-arrestin2 enhances beta2-adrenergic receptor-mediated nuclear translocation of ERK. Cell. Signal. 17, 1248-1253. doi: 10.1016/j.cellsig.2004.12.014

Koch, W. J., Rockman, H. A., Samama, P., Hamilton, R. A., Bond, R. A., Milano, C. A., et al. (1995). Cardiac function in mice overexpressing the $\beta$-adrenergic receptor kinase or a $\beta$ ARK inhibitor. Science 268, 1350-1353. doi: 10.1126/ science.7761854

Komolov, K. E., Du, Y., Duc, N. M., Betz, R. M., Rodrigues, J. P. G. L. M., Leib, R. D., et al. (2017). Structural and functional analysis of a $\beta 2$-adrenergic receptor complex with GRK5. Cell 169, 407-412. doi: 10.1016/j.cell.2017.03.047

Korzick, D., Xiao, R., Ziman, B., Koch, W., Lefkowitz, R., and Lakatta, E. (1997). Transgenic manipulation of beta-adrenergic receptor kinase modifies cardiac myocyte contraction to norepinephrine. Am. J. Physiol. 272, H590-H596. doi: 10.1152/ajpheart.1997.272.1.H590

Krueger, K. M., Daaka, Y., Pitcher, J. A., and Lefkowitz, R. J. (1997). The role of sequestration in $\mathrm{G}$ protein-coupled receptor resensitization. Regulation of $\beta 2$ adrenergic receptor dephosphorylation by vesicular acidification. J. Biol. Chem. 272, 5-8. doi: 10.1074/jbc.272.1.5

Kukin, M. L., Kalman, J., Charney, R., Levy, D. K., Buchholz-Varley, C., Ocampo, O. N., et al. (1999). Prospective, randomized comparison of effect of longterm treatment with metoprolol or carvedilol on symptoms, exercise, ejection fraction, and oxidative stress in heart failure. Circulation 102, 2646-2651. doi: 10.1161/01.CIR.99.20.2645

Kurose, H. (2011). Atypical actions of G protein-coupled receptor kinases. Biomol. Ther. 19, 390-397. doi: 10.4062/biomolther.2011.19.4.390

Lefkowitz, R. J., Rajagopal, K., and Whalen, E. J. (2006). New roles for beta-arrestins in cell signaling: not just for seven-transmembrane receptors. Mol. Cell. 24, 643-652. doi: 10.1016/j.molcel.2006.11.007

Lefkowitz, R. J., and Shenoy, S. K. (2005). Transduction of receptor signals by $\beta$-arrestins. Science 308, 512-517. doi: 10.1126/science.1109237

Li, H. L., Zhuo, M. L., Wang, D., Wang, A. B., Cai, H., Sun, L. H., et al. (2007). Targeted cardiac overexpression of A20 improves left ventricular performance and reduces compensatory hypertrophy after myocardial infarction. Circulation 115, 1885-1894. doi: 10.1161/CIRCULATIONAHA.106.656835

Licht, C. L., Marcussen, A. B., Wegener, G., Overstreet, D. H., Aznar, S., and Knudsen, G. M. (2009). The brain 5-HT4 receptor binding is down-regulated in the Flinders Sensitive Line depression model and in response to paroxetine administration. J. Neurochem. 109, 1363-1374. doi: 10.1111/j.1471-4159.2009. 06050.x 
Liggett, S. B., Cresci, S., Kelly, R. J., Syed, F. M., Matkovich, S. J., Hahn, H. S., et al. (2008). A GRK5 polymorphism that inhibits $\beta$-adrenergic receptor signaling is protective in heart failure. Nat. Med. $14,510-517$. doi: $10.1038 / \mathrm{nm}$ 1750

Liu, J. J., Horst, R., Katritch, V., Stevens, R. C., and Wuthrich, K. (2012). Biased signaling pathways in $\beta 2$-adrenergic receptor characterized by $19 F-N M R$. Science 335, 1106-1110. doi: 10.1126/science.1215802

López-Sendón, J., Swedberg, K., McMurray, J., Tamargo, J., Maggioni, A. P., Dargie, H., et al. (2004). Expert consensus document on $\beta$-adrenergic receptor blockers. Eur. Heart J. 25, 1341-1362. doi: 10.1016/j.ehj.2004.06.002

Luttrell, L. M., Ferguson, S. S., Daaka, Y., Miller, W. E., Maudsley, S., Della Rocca, G. J., et al. (1999). $\beta$-Arrestin-dependent formation of $\beta 2$ adrenergic receptor Src protein kinase complexes. Science 283, 655-661. doi: 10.1126/science.283. 5402.655

Luttrell, L. M., and Lefkowitz, R. J. (2002). The role of $\beta$-arrestins in the termination and transduction of G-protein-coupled receptor signals. J. Cell Sci. 115, 455465.

Luttrell, L. M., Roudabush, F. L., Choy, E. W., Miller, W. E., Field, M. E., Pierce, K. L., et al. (2001). Activation and targeting of extracellular signal-regulated kinases by $\beta$-arrestin scaffolds. Proc. Natl. Acad. Sci. U.S.A. 98, 2449-2454. doi: 10.1073/pnas.041604898

Lymperopoulos, A., Rengo, G., and Koch, W. J. (2013). Adrenergic nervous system in heart failure. Pathophysiol. Ther. Circ. Res. 113, 739-753. doi: 10.1161/ CIRCRESAHA.113.300308

Mangmool, S., Denkaew, T., Parichatikanond, W., and Kurose, H. (2017). $\beta$-Adrenergic receptor and insulin resistance in the heart. Biomol. Ther. 25, 44-56. doi: 10.4062/biomolther.2016.128

Mangmool, S., Denkaew, T., Phosri, S., Pinthong, D., Parichatikanond, W., Shimauchi, T., et al. (2016). Sustained $\beta$ AR stimulation mediates cardiac insulin resistance in a PKA-dependent manner. Mol. Endocrinol. 30, 118-132. doi: 10.1210/me.2015-1201

Mangmool, S., Haga, T., Kobayashi, H., Kim, K. M., Nakata, H., Nishida, M., et al. (2006). Clathrin required for phosphorylation and internalization of $\beta 2$ adrenergic receptor by $\mathrm{G}$ protein-coupled receptor kinase 2 (GRK2). J. Biol. Chem. 281, 31940-31949. doi: 10.1074/jbc.M602832200

Mangmool, S., Shukla, A. K., and Rockman, H. A. (2010). $\beta$-Arrestindependent activation of $\mathrm{Ca} 2+/$ calmodulin kinase II after $\beta 1$-adrenergic receptor stimulation. J. Cell. Biol. 189, 573-587. doi: 10.1083/jcb.200911047

Martini, J. S., Raake, P., Vinge, L. E., DeGeorge, B. R. Jr., Chuprin, J. K., Harris, D. M., et al. (2008). Uncovering G protein-coupled receptor kinase-5 as a histone deacetylase kinase in the nucleus of cardiomyocytes. Proc. Natl. Acad. Sci. U.S.A. 105, 12457-12462. doi: 10.1073/pnas.0803153105

Maurice, J. P., Shah, A. S., Kypson, A. P., Hata, J. A., White, D. C., Glower, D. D., et al. (1999). Molecular beta-adrenergic signaling abnormalities in failing rabbit hearts after infarction. Am. J. Physiol. 276, H1853-H1860.

McCorvy, J. D., Butler, K. V., Kelly, B., Rechsteiner, K., Karpiak, J., Betz, R. M., et al. (2018). Structure-inspired design of $\beta$-arrestin-biased ligands for aminergic GPCRs. Nat. Chem. Biol. 14, 126-134. doi: 10.1038/nchembio.2527

McCrink, K. A., Maning, J., Vu, A., Jafferjee, M., Marrero, C., Brill, A., et al. (2017). $\beta$-Arrestin2 improves post-myocardial infarction heart failure via sarco(endo)plasmic reticulum $\mathrm{Ca}^{2+}$-ATPase- dependent positive inotropy in cardiac myocytes. Hypertension 70, 972-981. doi: 10.1161/HYPERTENSIONAHA.117.09817

McDonald, P. H., Chow, C. W., Miller, W. E., Laporte, S. A., Field, M. E., Lin, F. T., et al. (2000). $\beta$-Arrestin 2: a receptor-regulated MAPK scaffold for the activation of JNK3. Science 290, 1574-1577. doi: 10.1126/science.290.5496.1574

Metra, M., Cas, L. D., Di Lenarda, A., and Poole-Wilson, P. (2005). $\beta$-blockers in heart failure: are pharmacological differences clinically important? Heart Fail. Rev. 9, 123-130. doi: 10.1023/B:HREV.0000046367.99002.a4

Mnie-Filali, O., Amraei, M. G., Benmbarek, S., Archer-Lahlou, E., PenasCazorla, R., Vilaro, M. T., et al. (2010). Serotonin 4 receptor (5-HT4R) internalization is isoform-specific: effects of 5-HT and RS67333 on isoforms A and B. Cell. Signal. 22, 501-509. doi: 10.1016/j.cellsig.2009.11.004

Mollova, M. Y., Katus, H. A., and Back, J. (2015). Regulation of CaMKII signaling in cardiovascular disease. Front. Pharmacol. 6:178. doi: 10.3389/fphar.2015.00178

Moore, C. A. C., Milano, S. K., and Benovic, J. L. (2007). Regulation of receptor trafficking by GRKs and arrestins. Annu. Rev. Physiol. 69, 451-482. doi: 10.1146/ annurev.physiol.69.022405.154712
Nakaya, M., Chikura, S., Watari, K., Mizuno, N., Mochinaga, K., Mangmool, S., et al. (2012). Induction of cardiac fibrosis by $\beta$-blocker in $G$ proteinindependent and $G$ protein-coupled receptor kinase $5 / \beta$-arrestin2-dependent signaling pathways. J. Biol. Chem. 287, 35669-35677. doi: 10.1074/jbc.M112. 357871

Nobles, K. N., Xiao, K. H., Ahn, S., Shukla, A. K., Lam, C. M., Rajagopal, S., et al. (2011). Distinct phosphorylation sites on the $\beta 2$-adrenergic receptor establish a barcode that encodes differential functions of $\beta$-arrestin. Sci. Signal. 4:ra51. doi: 10.1126/scisignal.2001707

Noma, T., Lemaire, A., Naga Prasad, S. V., Barki-Harrington, L., Tilley, D. G., Chen, J., et al. (2007). $\beta$-Arrestin-mediated $\beta 1$-adrenergic receptor transactivation of the EGFR confers cardioprotection. J. Clin. Invest. 117, 2445-2458. doi: 10.1172/JCI31901

Noor, N., Patel, C. B., and Rockman, H. A. (2011). $\beta$-Arrestin: a signaling molecule and potential therapeutic target for heart failure. J. Mol. Cell. Cardiol. 51, 534-541. doi: 10.1016/j.yjmcc.2010.11.005

Nuamnaichati, N., Sato, V. H., Moongkarndi, P., Parichatikanond, P., and Mangmool, S. (2018). Sustained $\beta$-AR stimulation induces synthesis and secretion of growth factors in cardiac myocytes that affect on cardiac fibroblast activation. Life Sci. 193, 257-269. doi: 10.1016/j.lfs.2017. 10.034

Oakley, R. H., Laporte, S. A., Holt, J. A., Barak, L. S., and Caron, M. G. (1999). Association of $\beta$-arrestin with $G$ protein-coupled receptors during clathrinmediated endocytosis dictates the profile of receptor resensitization. J. Biol. Chem. 274, 32248-32257. doi: 10.1074/jbc.274.45.32248

O’Hayre, M., Eichel, K., Avino, S., Zhao, X., Steffen, D. J., Feng, X., et al. (2017). Genetic evidence that $\beta$-arrestins are dispensable for the initiation of $\beta 2$-adrenergic receptor signaling to ERK. Sci. Signal. 10:eaal3395. doi: 10.1126/scisignal.aal3395

Patel, P. A., Tilley, D. G., and Rockman, H. A. (2009). Physiologic and cardiac roles of $\beta$-arrestins. J. Mol. Cell. Cardiol. 46, 300-308. doi: 10.1016/j.yjmcc.2008.11. 015

Pedersen, M. E., and Cockcroft, J. R. (2007). The vasodilatory beta-blockers. Curr. Hypertens. Rep. 9, 269-277. doi: 10.1007/s11906-007-0050-2

Penela, P., Murga, C., Ribas, C., Tutor, A. S., Peregrin, S., and Mayor, F. Jr. (2006). Mechanisms of regulation of $G$ protein-coupled receptor kinases (GRKs) and cardiovascular disease. Cardiovasc. Res. 69, 46-56. doi: 10.1016/j.cardiores. 2005.09.011

Penela, P., Ribas, C., and Mayor, F. Jr. (2003). Mechanisms of regulation of the expression and function of G protein-coupled receptor kinases. Cell. Signal. 15, 973-981. doi: 10.1016/S0898-6568(03)00099-8

Penn, R. B., Pronin, A. N., and Benovic, J. L. (2000). Regulation of G proteincoupled receptor kinases. Trends Cardiovasc. Med. 10, 81-89. doi: 10.1016/ S1050-1738(00)00053-0

Petrofski, J. P., and Koch, W. J. (2003). The $\beta$-adrenergic receptor kinase ( $\beta$ ARK1) in heart failure. J. Mol. Cell. Cardiol. 35, 1167-1174. doi: 10.1016/S00222828(03)00243-8

Ping, P., Anzai, T., Gao, M., and Hammond, H. K. (1997). Adenylyl cyclase and G protein receptor kinase expression during development of heart failure. Am. J. Physiol. Heart Circ. Physiol. 273, H707-H717. doi: 10.1152/ajpheart.1997.273.2. $\mathrm{H} 707$

Pitcher, J. A., Freedman, N. J., and Lefkowitz, R. J. (1998). G protein-coupled receptor kinases. Annu. Rev. Biochem. 67, 653-692. doi: 10.1146/annurev. biochem.67.1.653

Ponikowski, P., Voors, A. A., Anker, S. D., Bueno, H., Cleland, J. G. F., Coats, A. J. S., et al. (2016). 2016 ESC Guidelines for the diagnosis and treatment of acute and chronic heart failure. The Task Force for the diagnosis and treatment of acute and chronic heart failure of the European Society of Cardiology (ESC). Developed with the special contribution of the Heart Failure Association (HFA) of the ESC. Eur. Heart J. 37, 2129-2200. doi: 10.1093/eurheartj/ ehw128

Port, J. D., and Bristow, M. R. (2001). Altered $\beta$-adrenergic receptor gene regulation and signaling in chronic heart failure. J. Mol. Cell. Cardiol. 33, 887-905. doi: 10.1006/jmcc.2001.1358

Raake, P. W., Vinge, L. E., Gao, E., Boucher, M., Rengo, G., Chen, X., et al. (2008). G protein-coupled receptor kinase 2 ablation in cardiac myocytes before or after myocardial infarction prevents heart failure. Circ. Res. 103, 413-422. doi: 10.1161/CIRCRESAHA.107.168336 
Rahmeh, R., Damian, M., Cottet, M., Orcel, H., Mendre, C., Durroux, T., et al. (2012). Structural insights into biased G protein-coupled receptor signaling revealed by fluorescence spectroscopy. Proc. Natl. Acad. Sci. U.S.A. 109, 67336738. doi: 10.1073/pnas.1201093109

Rajagopal, K., Whalen, E. J., Violin, J. D., Stiber, J. A., Rosenberg, P. B., Premont, R. T., et al. (2006). $\beta$-Arrestin2-mediated inotropic effects of the angiotensin II type 1A receptor in isolated cardiac myocytes. Proc. Natl. Acad. Sci. U.S.A. 103, 16284-16289. doi: $10.1073 /$ pnas. 0607583103

Rajagopal, S., Rajagopal, K., and Lefkowitz, R. J. (2010). Teaching old receptors new tricks: biasing seven-transmembrane receptors. Nat. Rev. Drug Discov. 9, 373-386. doi: 10.1038/nrd3024

Rasmussen, S. G., DeVree, B. T., Zou, Y., Kruse, A. C., Chung, K. Y., Kobilka, T. S., et al. (2011). Crystal structure of the $\beta 2$ adrenergic receptor-Gs protein complex. Nature 477, 549-555. doi: 10.1038/nature10361

Reinkober, J., Tscheschner, T., Pleger, S. T., Most, P., Katus, H. A., Koch, W. J., et al. (2012). Targeting GRK2 by gene therapy for heart failure: benefits above $\beta$-blockade. Gene Ther. 19, 686-693. doi: 10.1038/gt.2012.9

Reiter, E., and Lefkowitz, R. J. (2006). GRKs and $\beta$-arrestins: roles in receptor silencing, trafficking and signaling. Trends Endocrinol. Metab. 17, 159-165. doi: $10.1016 /$ j.tem.2006.03.008

Rengo, G., Lymperopoulos, A., Leosco, D., and Koch, W. J. (2011). GRK2 as a novel gene therapy target in heart failure. J. Mol. Cell. Cardiol. 50, 785-792. doi: 10.1016/j.yjmcc.2010.08.014

Rockman, H. A., Chien, K. R., Choi, D. J., Iaccarino, G., Hunter, J. J., Ross, J. Jr., et al. (1998). Expression of a $\beta$-adrenergic receptor kinase 1 inhibitor prevents the development of myocardial failure in gene-targeted mice. Proc. Natl. Acad. Sci. U.S.A. 95, 7000-7005. doi: 10.1073/pnas.95.12.7000

Rockman, H. A., Choi, D. J., Rahman, N. U., Akhter, S. A., Lefkowitz, R. J., and Koch, W. J. (1996). Receptor-specific in vivo desensitization by the G protein coupled receptor kinase-5 in transgenic mice. Proc. Natl. Acad. Sci. U.S.A. 93, 9954-9959. doi: 10.1073/pnas.93.18.9954

Ryba, D. M., Li, J., Cowan, C. L., Russell, B., Wolska, B. M., and Solaro, R. J. (2017). Long-term biased $\beta$-arrestin signaling improves cardiac structure and function in dilated cardiomyopathy. Circulation 135, 1056-1070. doi: 10.1161/ CIRCULATIONAHA.116.024482

Salazar, N. C., Chen, J., and Rockman, H. A. (2007). Cardiac GPCRs: GPCR signaling in healthy and failing hearts. Biochim. Biophys. Acta 1768, 1006-1018. doi: 10.1016/j.bbamem.2007.02.010

Sato, P. Y., Chuprun, J. K., Schwatz, M., and Koch, W. J. (2015). The evolving impact of $\mathrm{G}$ protein-coupled receptor kinases in cardiac health and disease. Physiol. Rev. 95, 377-404. doi: 10.1152/physrev.00015.2014

Schumacher, S. M., Gao, E., Zhu, W., Chen, X., Chuprun, J. K., Feldman, A. M., et al. (2015). Paroxetine-mediated GRK2 inhibition reverses and remodeling after myocardial infarction. Sci. Transl. Med. 7:277ra31. doi: 10. 1126/scitranslmed.aaa0154

Setyawan, J., Koide, K., Diller, T. C., Bunnage, M. E., Taylor, S. S., Nicolaou, K. C., et al. (1999). Inhibition of protein kinases by balanol: specificity within the serine/threonine protein kinase subfamily. Mol. Pharmacol. 56, 370-376. doi: 10.1124/mol.56.2.370

Shah, A. S., White, D. C., Emani, S., Kypson, A. P., Lilly, R. E., Wilson, K., et al. (2001). In vivo ventricular gene delivery of a $\beta$-adrenergic receptor kinase inhibitor to the failing heart reverses cardiac dysfunction. Circulation 103, 1311-1316. doi: 10.1161/01.CIR.103.9.1311

Shenoy, S. K., Drake, M. T., Nelson, C. D., Houtz, D. A., Xiao, K., Madabushi, S., et al. (2006). $\beta$-Arrestin-dependent, G protein-independent ERK1/2 activation by the $\beta 2$ adrenergic receptor. J. Biol. Chem. 281, 1261-1273. doi: 10.1074/jbc. M506576200

Shenoy, S. K., McDonald, P. H., Kohout, T. A., and Lefkowitz, R. J. (2001). Regulation of receptor fate by ubiquitination of activated $\beta 2$-adrenergic receptor and $\beta$-arrestin. Science 294, 1307-1313. doi: 10.1126/science.106 3866

Shiina, T., Arai, K., Tanabe, S., Yoshida, N., Haga, T., Nagao, T., et al. (2001). Clathrin box in G protein-coupled receptor kinase 2. J. Biol. Chem. 276, 33019-33026. doi: 10.1074/jbc.M100140200

Shiina, T., Kawasaki, A., Nagao, T., and Kurose, H. (2000). Interaction with $\beta$-arrestin determines the difference in internalization behavior between beta1and beta2-adrenergic receptors. J. Biol. Chem. 275, 29082-29090. doi: 10.1074/ jbc.M909757199
Shukla, A. K., Violin, J. D., Whalen, E. J., Gesty-Palmer, D., Shenoy, S. K., and Lefkowitz, R. J. (2008). Distinct conformational changes in $\beta$-arrestin report biased agonism at seven-transmembrane receptors. Proc. Natl. Acad. Sci. U.S.A. 105, 9988-9993. doi: 10.1073/pnas.0804246105

Sulakhe, P. V., and Vo, X. T. (1995). Regulation of phospholamban and troponin-I phosphorylation in the intact rat cardiomyocytes by adrenergic and cholinergic stimuli. Mol. Cell. Biochem. 149-150, 103-126. doi: 10.1007/BF0107 6569

Suzuki, T., Nguyen, C. T., Nantel, F., Bonin, H., Valiquette, M., Frielle, T., et al. (1992). Distinct regulation of beta1- and beta2-adrenergic receptors in Chinese hamster fibroblasts. Mol. Pharmacol. 41, 542-548.

Tan, C. M., Brady, A. E., Nickols, H. H., Wang, Q., and Limbird, L. E. (2004). Membrane trafficking of G protein-coupled receptors. Annu. Rev. Pharmacol. Toxicol. 44, 559-609. doi: 10.1146/annurev.pharmtox.44.101802.121558

Tesmer, J. J., Tesmer, V. M., Lodowski, D. T., Steinhagen, H., and Huber, J. (2010). Structure of human G protein-coupled receptor kinase 2 in complex with the kinase inhibitor balanol. J. Med. Chem. 53, 1867-1870. doi: 10.1021/jm9017515

Thal, D. M., Homan, K. T., Chen, J., Wu, E. K., Hinkle, P. M., Huang, Z. M., et al. (2012). Paroxetine is a direct inhibitor of $G$ protein-coupled receptor kinase 2 and increases myocardial contractility. ACS Chem. Biol. 7, 1830-1839. doi: $10.1021 / \mathrm{cb} 3003013$

Thal, D. M., Yeow, R. Y., Schoenau, C., Huber, J., and Tesmer, J. J. (2011). Molecular, mechanism of selectivity among $\mathrm{G}$ protein-coupled receptor kinase 2 inhibitors. Mol. Pharmacol. 80, 294-303. doi: 10.1124/mol.111.071522

Thanawala, V. J., Forkuo, G. S., Stallaert, W., Paul, L., Bouvier, M., and Bond, R. (2014). Ligand bias prevents class equality among beta-blockers. Curr. Opin. Pharmacol. 16, 50-57. doi: 10.1016/j.coph.2014.03.002

Tran, T. M., Jorgensen, R., and Clark, R. B. (2007). Phosphorylation of the beta2adrenergic receptor in plasma membranes by intrinsic GRK5. Biochemistry 46, 14438-14449. doi: 10.1021/bi700922h

Tzingounis, A. V., von Zastrow, M., and Yudowski, G. A. (2010). $\beta$-Blocker drugs mediate calcium signaling in native central nervous system neurons by $\beta$-arrestin-biased agonism. Proc. Natl. Acad. Sci. U.S.A. 107, 21028-21033. doi: $10.1073 /$ pnas. 1004169107

Ungerer, M., Bohm, M., Elce, J. S., Erdmann, E., and Lohse, M. J. (1993). Altered expression of $\beta$-adrenergic receptor kinase and $\beta 1$-adrenergic receptors in the failing human heart. Circulation 87, 454-463. doi: 10.1161/01.CIR.87. 2.454

Ungerer, M., Kessebohm, K., Kronsbein, K., Lohse, M. J., and Richardt, G. (1996). Activation of $\beta$-adrenergic receptor kinase during myocardial ischemia. Circ. Res. 79, 455-460. doi: 10.1161/01.RES.79.3.455

Ungerer, M., Parruti, G., Bohm, M., Puzicha, M., DeBlasi, A., Erdmann, E., et al. (1994). Expression of $\beta$-arrestins and $\beta$-adrenergic receptor kinases in the failing human heart. Circ. Res. 74, 206-213. doi: 10.1161/01.RES.74.2.206

Vidal, R., Valdizan, E. M., Mostany, R., Pazos, A., and Castro, E. (2009). Long-term treatment with fluoxetine induces desensitization of 5-HT4 receptor-dependent signalling and functionality in rat brain. J. Neurochem. 110, 1120-1127. doi: 10.1111/j.1471-4159.2009.06210.x

Vinge, L. E., Oie, E., Andersson, Y., Grogaard, H. K., Anderson, G., and Attramadal, H. (2001). Myocardial distribution and regulation of GRK and $\beta$-arrestin isoforms in congestive heart failure in rats. Am. J. Physiol. Heart Circ. Physiol. 281, H2490-H2499. doi: 10.1152/ajpheart.2001.281.6.H2490

Violin, J. D., and Lefkowitz, R. J. (2007). $\beta$-Arrestin-biased ligands at seventransmembrane receptors. Trends Pharmacol. Sci. 28, 416-422. doi: 10.1016/j. tips.2007.06.006

Violin, J. D., Ren, X. R., and Lefkowitz, R. J. (2006). G-protein-coupled receptor kinase specificity for $\beta$-arrestin recruitment to the $\beta 2$ - adrenergic receptor revealed by fluorescence resonance energy transfer. J. Biol. Chem. 281, 2057720588. doi: 10.1074/jbc.M513605200

Volovyk, Z. M., Wolf, M. J., Prasad, S. V., and Rockman, H. A. (2006). Agonist-stimulated beta-adrenergic receptor internalization requires dynamic cytoskeletal actin turnover. J. Biol. Chem. 281, 9773-9780. doi: 10.1074/jbc. M511435200

von Leuder, T. G., Gravning, J., How, O. J., Vinge, L. E., Ahmed, M. S., Krobert, K. A., et al. (2012). Cardiomyocyte-restricted inhibition of $\mathrm{G}$ proteincoupled receptor kinase-3 attenuates cardiac dysfunction after chronic pressure overload. Am. J. Physiol. Heart Circ. Physiol. 303, H66-H74. doi: 10.1152/ ajpheart.00724.2011 
Waldschmidt, H. V., Bouley, R., Kirchhoff, P. D., Lee, P., Tesmer, J. J., and Larsen, S. D. (2018). Utilizing a structure-based docking approach to develop potent $G$ protein-coupled receptor kinase (GRK) 2 and 5 inhibitors. Bioorg. Med. Chem. Lett. 28, 1507-1515. doi: 10.1016/j.bmcl.2018.03.082

Warne, T., and Tate, C. G. (2013). The importance of interactions with helix 5 in determining the efficacy of $\beta$-adrenoceptor ligands. Biochem. Soc. Trans. 41, 159-165. doi: 10.1042/BST20120228

Watari, K., Nakay, M., and Kurose, H. (2014). Multiple functions of G proteincoupled receptor kinases. J. Mol. Signal. 9:1. doi: 10.1186/1750-2187-9-1

Watari, K., Nakaya, M., Nishida, M., Kim, K. M., and Kurose, H. (2013). $\beta$-Arrestin2 in infiltrated macrophages inhibits excessive inflammation after myocardial infarction. PLoS One 8:e68351. doi: 10.1371/journal.pone.00 68351

White, D. C., Hata, J. A., Shah, A. S., Glower, D. D., Lefkowitz, R. J., and Koch, W. J. (2000). Preservation of myocardial $\beta$-adrenergic receptor signaling delays the development of heart failure after myocardial infarction. Proc. Natl. Acad. Sci. U.S.A. 97, 5428-5433. doi: 10.1073/pnas.09009 1197

Williams, M. L., Hata, J. A., Shroder, J., Rampersaud, E., Petrofski, J., Jakoi, A., et al. (2004). Targeted $\beta$-adrenergic receptor kinase ( $\beta$ ARK1) inhibition by gene transfer in failing human hearts. Circulation 109, 1590-1593. doi: 10.1161/01. CIR.0000125521.40985.28

Winstel, R., Ihlenfeldt, H. G., Jung, G., Krasel, C., and Lohse, M. J. (2005). Peptide inhibitors of $\mathrm{G}$ protein-coupled receptor kinases. Biochem. Pharmacol. 70, 1001-1008. doi: 10.1016/j.bcp.2005.06.015

Wisler, J. W., DeWire, S. M., Whalen, E. J., Violin, J. D., Drake, M. T., Ahn, S., et al. (2007). A unique mechanism of $\beta$-blocker action. Carvedilol stimulates $\beta$-arrestin signaling. Proc. Natl. Acad. Sci. U.S.A. 104, 16657-16662. doi: 10. 1073/pnas.0707936104

Wisler, J. W., Xiao, K., Thomsen, A. R., and Lefkowitz, R. J. (2014). Recent developments in biased agonism. Curr. Opin. Cell Biol. 27, 18-24. doi: 10.1016/ j.ceb.2013.10.008

Woo, A. Y., Jozwiak, K., Toll, L., Tanga, M. J., Kozocas, J. A., Jimenez, L., et al. (2014). Tyrosine 308 is necessary for ligand-directed Gs protein-biased signaling of $\beta 2$-adrenoceptor. J. Biol. Chem. 289, 19351-19363. doi: 10.1074/ jbc.M114.558882
Woodall, M. C., Woodall, B. P., Gao, E., Yuan, A., and Koch, W. J. (2016). Cardiac fibroblast GRK2 deletion enhances contractility and remodeling following ischemia/reperfusion injury. Circ. Res. 119, 1116-1127. doi: 10.1161/ CIRCRESAHA.116.309538

Wu, N., Hanson, S. M., Francis, D. J., Vishnivetskiy, S. A., Thibonnier, M., Klug, C. S., et al. (2006). Arrestin binding to calmodulin: a direct interaction between two ubiquitous signaling proteins. J. Mol. Biol. 364, 955-963. doi: 10.1016/j.jmb. 2006.09.075

Xiao, K., McClatchy, D. B., Shukla, A. K., Zhao, Y., Chen, M., Shenoy, S. K., et al. (2007). Functional specialization of $\beta$-arrestin interactions revealed by proteomic analysis. Proc. Natl. Acad. Sci. U.S.A. 104, 12011-12016. doi: 10.1073/ pnas.0704849104

Yamamoto, K. (2017). Pharmacological treatment of heart failure with preserved ejection fraction. Yonago Acta Med. 60, 71-76.

Yang, X., Zhou, G., Ren, T., Li, H., Zhang, Y., Yin, D., et al. (2012). $\beta$-Arrestin prevents cell apoptosis through pro-apoptotic ERK1/2 and p38 MAPKs and anti-apoptotic Akt pathways. Apoptosis 17, 1019-1026. doi: 10.1007/s10495012-0741-2

Yi, X. P., Gerdes, A. M., and Li, F. (2002). Myocyte redistribution of GRK2 and GRK5 in hypertensive, heart-failure-prone rats. Hypertension 39, 1058-1063. doi: 10.1161/01.HYP.0000019130.09167.3B

Zhang, R., Zhao, J., Mandveno, A., and Potter, J. D. (1995). Cardiac troponin I phosphorylation increases the rate of cardiac muscle relaxation. Circ. Res. 76, 1028-1035. doi: 10.1161/01.RES.76.6.1028

Conflict of Interest Statement: The authors declare that the research was conducted in the absence of any commercial or financial relationships that could be construed as a potential conflict of interest.

Copyright $\odot 2018$ Mangmool, Parichatikanond and Kurose. This is an open-access article distributed under the terms of the Creative Commons Attribution License (CC BY). The use, distribution or reproduction in other forums is permitted, provided the original author(s) and the copyright owner(s) are credited and that the original publication in this journal is cited, in accordance with accepted academic practice. No use, distribution or reproduction is permitted which does not comply with these terms. 